\title{
Republic of the Marshall Islands: 2009 Article IV Consultation-Staff Report; a Public Information Notice; and a Statement by the Executive Director of the Republic of Marshall islands on the Executive Board Discussion.
}

Under Article IV of the IMF's Articles of Agreement, the IMF holds bilateral discussions with members, usually every year. In the context of the 2009 Article IV consultation with the Republic of the Marshall Islands, the following documents have been released and are included in this package:

- $\quad$ The staff report for the 2009 Article IV consultation, prepared by a staff team of the IMF, following discussions that ended on November 18, 2009, with the officials of the Republic of the Marshall Islands on economic developments and policies. Based on information available at the time of these discussions, the staff report was completed on January 15, 2010. The views expressed in the staff report are those of the staff team and do not necessarily reflect the views of the Executive Board of the IMF.

- $\quad$ A Public Information Notice (PIN) summarizing the views of the Executive Board as expressed during its February 1, 2010 discussion of the staff report that concluded the Article IV consultation.

- $\quad$ A statement by the Executive Director for the Republic of Marshall Islands.

The policy of publication of staff reports and other documents allows for the deletion of market-sensitive information.

Copies of this report are available to the public from

International Monetary Fund $\bullet$ Publication Services

$70019^{\text {th }}$ Street, N.W. • Washington, D.C. 20431

Telephone: (202) 623-7430 • Telefax: (202) 623-7201

E-mail: publications@imf.org・Internet: http://www.imf.org

\section{International Monetary Fund Washington, D.C.}




\title{
INTERNATIONAL MONETARY FUND
}

\author{
REPUBLIC OF THE MARSHALL ISLANDS
}

\section{Staff Report for the 2009 Article IV Consultation}

Prepared by the Staff Representatives for the 2009 Consultation with the Republic of the Marshall Islands

Approved by Kenneth Kang and Aasim Husain

January 15,2010

- Discussions. November 10-18, 2009 with Finance Minister Ading, Chief Secretary Nemra, Finance Secretary Barton, Banking Commissioner Muller, other senior government officials, private-sector participants, donors, and the press.

- Team. Mr. Danninger (head), Ms. Berkmen (both APD), and Mr. Mellor (AsDB). Mr. Moon (OED) participated in the discussions. Representatives of the World Bank participated in the mission as observers.

- Outreach. Staff presented its findings to the President and the Cabinet of Ministers, held a meeting open to all interlocutors, and gave a press interview.

- Mission focus. Discussions focused on policies to secure a sustained recovery and long-term economic and fiscal sustainability.

- Exchange rate. The Marshall Islands has accepted the obligations of Article VIII, Sections 2,3, and 4 . The exchange system is free of restrictions on the making of payments and transfers for current international transactions. The U.S. dollar is legal tender.

- Technical assistance. Pacific Financial Technical Assistance Centre (PFTAC) has provided assistance in bank supervision, cash management, tax policy and revenue administration, and balance of payments statistics.

- Statistical issues. The quality of official statistics is adequate for surveillance. Reliability, coverage, and timeliness of official statistics could be strengthened.

- Past Fund advice. The authorities broadly agreed with staff's recommendation of a need for fiscal adjustment and reforms to promote private sector development. However, implementation has been held back by frequent changes in government. 


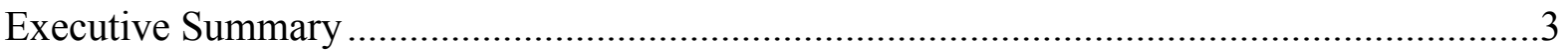

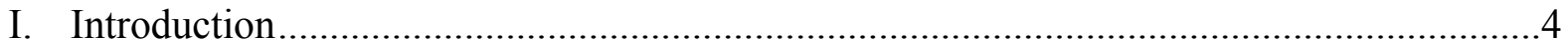

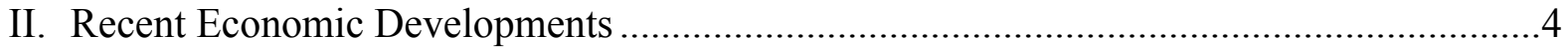

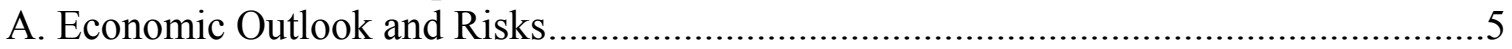

III. Policies to Achieve Sustainable Growth.................................................................... 6

A. Fiscal Adjustment and Public Sector Modernization..............................................6

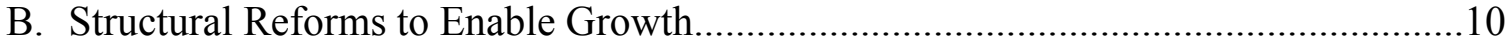

C. External Stability and Exchange Rate................................................................... 11

D. Financial Sector ........................................................................................... 11

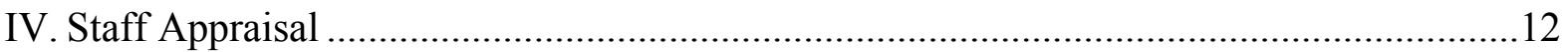

\section{Boxes}

1. Tax Policy Modernization: Current System and Reform Options ................................. 9

Figures

1. Regional Comparison of Recent Developments ...................................................... 14

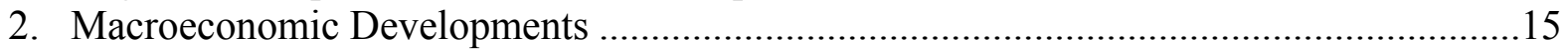

3. Developments in Export Growth and the Exchange Rate (2000-08) ............................16

\section{Tables}

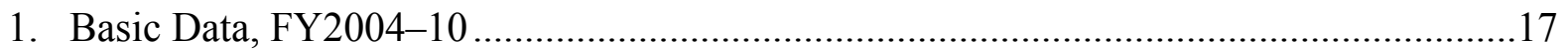

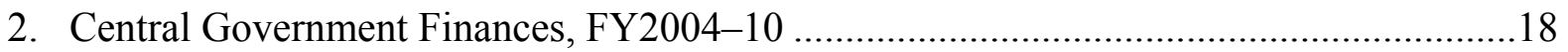

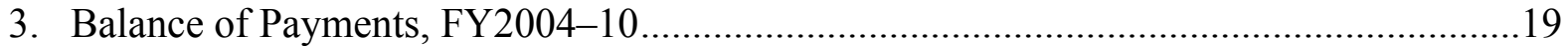

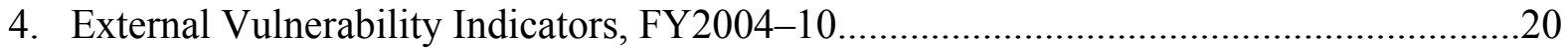

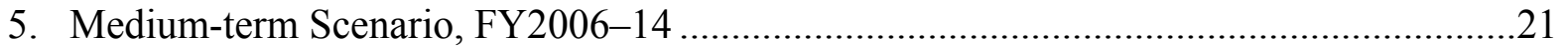

Appendix

Long-term Fiscal Sustainability 


\section{EXECUTIVE SUMMARY}

Economic and political environment. The commodity and food prices boom took a sharp toll on the economy and led in 2008 to the first recession in 10 years. The political environment remains difficult. In October of 2009, the third government in as many years took office. Achieving consensus on important fiscal reforms remains difficult.

Outlook and risks. The economy is on a path to recovery, but the cresting of foreign grants, which fueled domestic demand in the past, will slow down the underlying growth momentum. Risks to the economic outlook are tilted to the downside. The economy's high import dependence means that fluctuations in commodity prices pose a substantial risk to real incomes and additional donor assistance is more difficult to secure than in the past.

Fiscal sustainability. Achieving long-term budgetary self-reliance and sustained growth have become more challenging after the global crisis. Under current projections, weakened growth prospects and lower than anticipated asset values in the government's trust fund imply a large projected revenue shortfall in 2024, when the grant based public funding scheme expires. Closing this revenue gap requires a medium-term fiscal adjustment to a 5 percent of GDP surplus.

Fiscal and growth enhancing reforms. A comprehensive public sector modernization program that builds on local reform initiatives could secure fiscal sustainability and unlock growth in the private sector. Its key elements are: (i) achieving lasting fiscal surpluses to replenish the trust fund to provide long-term fiscal revenue; (ii) modernizing the public sector through civil service, tax, and state owned enterprise reform; (iii) and enabling private sector growth through improved infrastructure services and better access to commercial bank loans.

Banking sector. The banking system remains profitable, but contributes little to economic growth. The vast majority of private lending is directed to consumers and rising household debt needs to be carefully monitored. Activities by the public development bank are currently not regulated and should be brought under the supervision of the Banking Commission. 


\section{INTRODUCTION}

1. Large and stable external grants have buttressed economic growth in the Republic of the Marshall Islands (RMI), but access to these foreign funds is time limited. The 2004 Compact of Free Association with the United States (Compact) provides a 20-year stream of funding aimed primarily at education, health, and infrastructure projects. These grants have been a boon to social and economic growth, but come at the expense of fostering economic dependence on foreign income. By 2024, when Compact grants expire, the RMI will have to rely on income from its Compact Trust Fund (CTF), but on current projections, a large revenue shortfall looms.

2. Achieving economic and fiscal self-sufficiency remains a formidable challenge and is exacerbated by a difficult political environment. Like other small Pacific island countries, the Republic of the RMI is vulnerable to external shocks and its remoteness and structural barriers have suppressed the development of a vibrant business sector. The low private sector growth potential and the scheduled phasing out of grant assistance require decisive policy measures to put the economy on a sound footing. Reaching political consensus on key reforms, however, has been challenging. In October 2009, the third government in as many years took office reflecting the difficulties in transitioning from a traditional tribal system to a modern democracy.

3. This year's discussions focused on policies to secure a sustained recovery and longterm economic and fiscal sustainability. The global crisis has taken a sharp toll on the economy and led to the first recession in 10 years. ${ }^{1}$ Domestic inflation peaked at 29 percent in the third quarter of 2008 leading to a large decline in real incomes and straining public finances like in many other countries in the region (Figure 1). For policy makers, the crisis was a wake-up call, highlighting the need to modernize the public sector and improve private sector growth and employment prospects. Achieving this goal requires fiscal consolidation, a reform of public enterprises, and structural measures to promote growth.

\section{RECENT ECONOMIC DEVELOPMENTS}

\section{Following a contraction in the previous year, the economy stabilized in 2009}

(Figure 2). The opening of a fish loining factory and reported increases of remittances provided new impulses to demand. The recovery was also helped by a reversal of the large 2008 terms of trade shock as sharply falling domestic food and energy prices arrested the erosion of household incomes. Inflation declined to 0.5 percent in 2009 after reaching 14.7 percent in $2008{ }^{2}$ These positive growth contributions were, however, largely offset by job losses due to a reduction in personnel at the U.S. military base in Kwajelein and a decline in tourism.

\footnotetext{
1 Annual data refer to the fiscal year ending in September.

${ }^{2}$ Almost all of the increase was driven by food, utilities, and transport price increases, reflecting changes in world commodity prices.
} 
5. The fiscal balance remained in deficit in 2009. Staff estimates the deficit at 0.2 percent of GDP, roughly unchanged from 2008. Lack of access to capital markets and limited financial assets provided little room to adjust to the large terms of trade shock. Thanks to additional grants from donors and higher non-tax income from ship registration fees, the government was able to offset lower tax revenue, and to finance tax exemptions granted for imported food and fuel products and higher subsidies to state-owned enterprises (SOEs).

6. The level of public debt remains high, but assets in the Compact Trust and Social Security Funds have begun to recover. Government and government guaranteed debt remained stable at 62 percent of GDP in 2008 and is mostly on concessional terms (40 percent of GDP owed to the Asian Development Bank (AsDB)). The collapse in global equity markets in 2008 led to significant losses for the CTF (-22.6 percent excluding new contributions), but the value of assets recovered to a large degree since then and stands at $\$ 97.3$ million (63 percent of GDP) at the end of fiscal year 2009. Similarly, the Social Security Fund rebounded to $\$ 65.7$ million (46 percent of GDP) in 2009, but remained below its 2007 peak.

\section{Exports have increased modestly over the last decade held back by structural} problems rather than lack of price competitiveness (Figure 3). Similar to other Pacific Island economies, a low inflation rate, closely tracking U.S. consumer price developments, kept the real exchange rate steady. ${ }^{3}$ The real effective exchange rate appreciated significantly in 2008 with the pass-through of high commodity and food price inflation, but reversed by the second half of 2009. Growth in the tradable sector has been sluggish mainly due to a difficult business environment and remoteness from international markets. ${ }^{4}$

\section{A. Economic Outlook and Risks}

8. The mission projected a gradual economic recovery over the near term. Activity in 2010 is forecast to improve moderately to 0.5 percent, supported by a further expansion in the fish processing industry and additional foreign grant assistance (Taiwan, Province of China and the European Union). However, the cresting of Compact grants disbursements, which have supported domestic demand, and structural weaknesses in the private sector will slow the underlying growth momentum. Inflation is projected to rise to 1.5 percent, in line with price developments in the United States given the large share of imported goods in the CPI basket and a projected moderate increase in commodity prices.

9. Risks to the economic outlook are tilted to the downside. The economy's high import dependence means that fluctuations in commodity prices pose a substantial risk to real incomes. Rising prices could stoke inflation and stifle domestic demand. In the current, weak global economic environment, donor assistance may also be more difficult to secure, posing another

\footnotetext{
${ }^{3}$ The U.S. dollar is the official currency.

${ }^{4}$ The recent decline in tourism, for instance, was related to unreliable domestic air transportation services by the state-owned airline.
} 
downside risk to growth. On the upside, the planned regional collaboration on managing the regional fish-stock (Pacific Nauru Agreement) to capture a higher share of fishing profits by coastal countries could generate a new source of income and growth, but these benefits likely take time to materialize.

10. The authorities agreed with staff's assessment and emphasized upside risks as growth prospects in the fishing sector had improved. The mission acknowledged these positive risks, but noted that the economy will likely grow more slowly over the medium term compared to previous years. The scheduled annual decline in Compact grant assistance will only be partially offset by income generated from planned expansions in the fish-processing sector and a recovery in tourism. Staff projects that growth will level off at 1.5 percent in the medium term — well below the average rate of 2.7 percent in 2004-07.

\section{Policies to Achieve Sustainable Growth}

\section{A. Fiscal Adjustment and Public Sector Modernization}

\section{Achieving long-term budgetary self-reliance and sustained growth have become} more challenging after the global crisis. Weakened growth prospects and lower than anticipated CTF asset values imply a projected revenue shortfall - the difference between expiring Compact grants and CTF income - of 9 percent of GDP in 2024 (\$16 million in 2009 dollars) (Appendix I). Closing this revenue gap will require a significant adjustment effort to be progressively built over the medium term. The mission assessed that a fiscal surplus of 5 percent of GDP (\$9 million) would have to be achieved by 2014 and maintained until 2023 to secure budgetary selfsufficiency. $^{5}$

\section{The government recognized the need for}

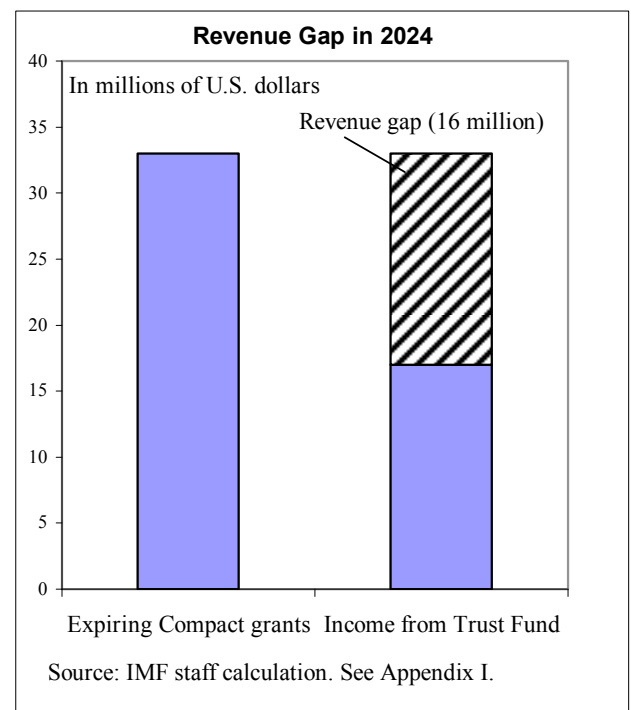
fiscal adjustment and expressed its intention to target a fiscal surplus in 2010 to increase savings in the CTF. The 2010 budget foresees savings from the elimination of vacant positions and growing revenue from ship registry payments. The mission welcomed these plans, but noted that it would be difficult to achieve a sufficiently large surplus since growing public debt service

\footnotetext{
${ }^{5}$ By putting the savings into the CTF, projected income would be large enough to offset the revenue shortfall from expiring grants, while preserving the asset base in the CTF.
} 
$\operatorname{costs}^{6}$ (grace periods on concessional loans expire) and more subsidies for the electricity utility will likely more than absorb the savings.

\section{The mission noted that comprehensive public sector reform would help achieve}

fiscal and economic sustainability. Such reforms should be based on three objectives:

(i) achieving lasting fiscal surpluses to supplement the CTF; (ii) modernizing the public sector through civil service, tax, and state owned enterprise reform to improve its efficiency and effectiveness; (iii) and providing an enabling environment to develop a growth engine independent from the Compact. The authorities concurred and noted that two reform commissions, the Comprehensive Adjustment Program (CAP) group, tasked with identifying expenditure reforms, and the Tax and Revenue Reform and Modernization Commission (TRRM) had prepared reports on reform plans. Staff recommended that the government transform these initiatives into a comprehensive program.

14. The authorities agreed that both expenditure cuts and revenue gains were necessary to achieve the needed fiscal adjustment. Since revenue measures would take time to prepare and implement, expenditure cuts had to be taken first. In designing its adjustment program, the mission suggested that the government weigh carefully the cost and efficiency implications. The authorities agreed, but cautioned that economic and social implications also had to be assessed carefully.

\section{The mission advised the following elements of an expenditure reform strategy:}

\section{- Civil service rationalization. The} public sector wage bill has doubled since 2000 primarily due to a rise in the public payroll and, at 22 percent of GDP, is significantly higher than in other countries in the region. The mission welcomed the plan to conduct a comprehensive civil service personnel audit to identify areas of over-staffing and disproportionate pay. Building on the audit's findings, a combination of civil service pay cuts and reductions in

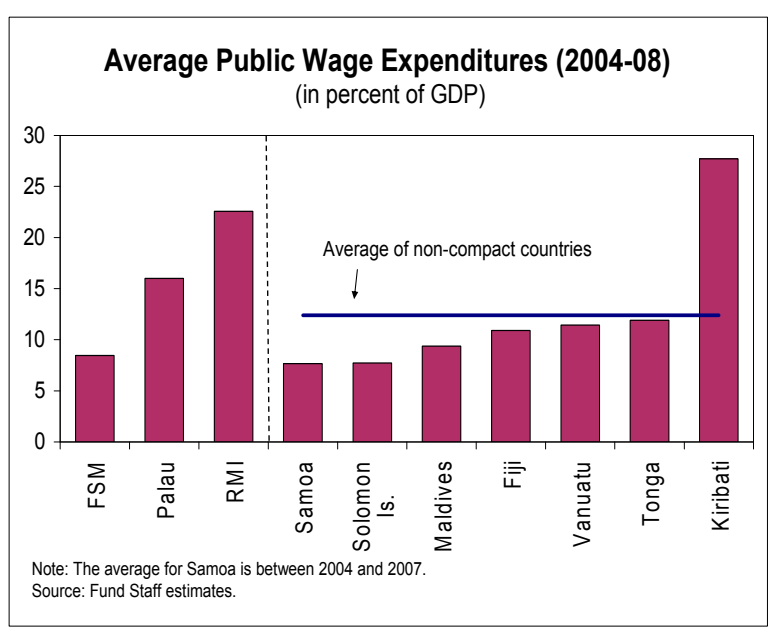
employment should be phased over the near term.

- Limiting financial support to SOEs. Although the public agency reforms were successful in some cases (for example, the social security administration), many public enterprises continue to be a drain on the budget. Cumulative public support to SOEs

\footnotetext{
${ }^{6}$ Amortization payments on central government debt to AsDB are estimated to grow to 1.2 percent of GDP over the medium-term.
} 
through subsidies, net cash advances, and capital injections added up to 18 percent of GDP in the last five years (\$27 million), with Marshalls Electrical Company (MEC) and Air Marshall Islands (AMI) being the largest recipients. The mission recommended ceasing general subsidization of energy consumption by raising electricity tariffs to cover production costs and to encourage conservation. Import duty exemptions to the MEC should be reversed, and public financial support through the granting of advances for future electricity services should be made explicit in the budget.

- Cutting other expenditures. Allowances to

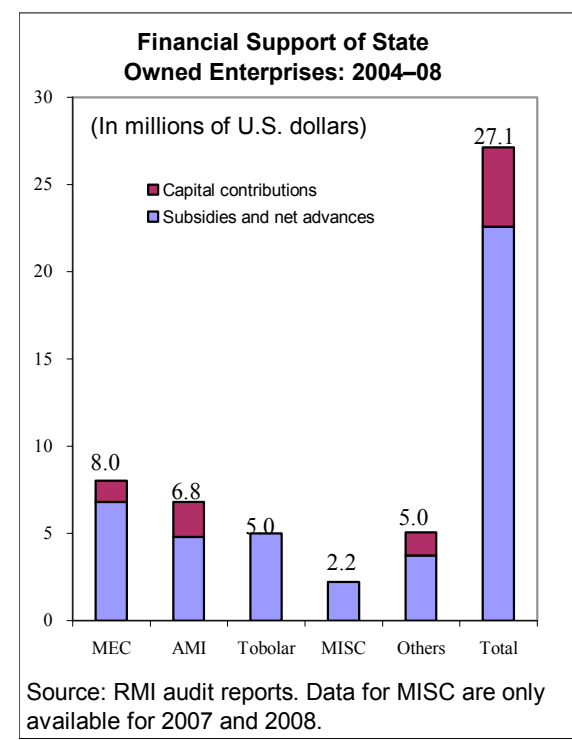
civil servants and public officials (such as housing and electricity) come at a large annual cost to the budget (1.2 percent of GDP) and are not well targeted. The mission supported the CAP's recommendation to minimize these allowances, which would reduce the operational losses of the electricity utility.

16. The authorities agreed with the priorities for expenditure cuts, but argued that reductions of the public work force could have a broad economic and social impact. Reducing public sector employment could deprive large family-groups of income given that the private sector was unlikely to absorb any shed labor and the absence of a social safety net. Instead, the authorities preferred reductions in hours-worked and enforcement of mandatory retirement rules. Staff recognized these challenges, but noted that a shift to part-time employment risked a policy reversal and preserved the large public-private sector wage differential, which was crowding out private employment.

17. On revenue measures, the mission supported the authorities' plan to modernize the tax system. The existing tax system lacks the ability to raise additional revenue, fails to encourage private investment, and is inequitable. The gross revenue tax (GRT) has a cascading effect, and the proliferation of small taxes has complicated tax administration. Finally, many sources of income are exempt generating inequity. On this basis, the mission recommended:

- Adoption of a comprehensive tax reform program. The mission recommended that the TRRM Commission's proposal be based on a PFTAC developed tax reform plan (Box 1). The plan should be accepted as a uniform package of measures and tax rates and registration levels set in order to generate additional revenue. Given the amount of preparatory work and time required for implementation (up to 36 months), the mission recommended priority be given to drafting the needed legislation.

- Unification of tax administration. The mission noted that while tax enforcement had been stepped up, administrative capabilities needed to be strengthened. Improved audit 
activities at the social security administration had already led to a sizeable reduction in unpaid contributions and improved compliance. Since there are significant gains to be made from harmonizing collection processes and information sharing, the mission advised the establishment of a unified revenue administration as part of the tax reform.

\section{Box 1. Tax Policy Modernization: Current System and Reform Options}

Relative to the size of the fiscal adjustment over the medium term, the current tax system is unlikely to generate additional revenue. The annual revenue yield of 18 percent of GDP is below those in other economies, which have introduced tax regimes based on international practice (26 percent of GDP in Samoa and Tonga in 2007). The low yield potential is the result of an outdated tax system and low compliance (see IMF 2008 Selected Issues).

PFTAC has proposed a reform strategy centered around four basic changes aimed at raising efficiency, removing distortions, and increasing revenue while attempting to keep tax rates low.

(1) Replacing the GRT and a number of specific business taxes and duties with a broad based consumption tax, to eliminate cascading, strengthen compliance, and simplify the tax system;

(2) Introducing a net profit tax for large businesses while retaining the GRT for small businesses. The net profit tax would eliminate tax cascading, remove disincentives for investment, and lead to more equal taxation across different types of businesses; only the largest 25 percent of businesses would fall under the new net-profit tax;

(3) Replacing the existing import duties and local government taxes on alcohol, tobacco, motor vehicles and fuel with similar excises, which would make them acceptable revenue sources for regional trade agreements; and

(4) Modifying the wages and salaries tax by broadening the tax base to include items, which are currently exempt, modifying and expanding the current tax-free threshold so that it is available to all taxpayers, and introducing a higher tax rate for high income earners.

The economic impact of the new tax system on growth would likely be small, as efficiency gains outweigh negative growth effects. Successful reform examples of consumption tax reform include Fiji and Samoa, and more recently Tonga. Preliminary estimates for the RMI point to a positive revenue impact of between \$2 and \$8 million (1.4-5.5 percent of GDP) in the medium term, depending on the level of statutory rates for consumption and net profit taxes and chosen registration threshold levels.

18. The mission cautioned that unfunded liabilities of the social security system were a sizeable contingent liability. The 2009 actuarial report identified $\$ 180$ million of unfunded liabilities (120 percent of GDP). In past years, rising benefit payments have been covered by aggressively pursuing accounts receivables and by drawing on investment income. Rapidly rising benefits will, however, begin to erode fund assets in the near term. In light of the worsening financial situation, the mission recommended that the authorities consider an adjustment plan featuring various possible options. The authorities noted that they were exploring future funding options including a reduction in benefits, increase of contribution rates, and a transition to a defined contribution system. 
19. The government welcomed the idea to use its recent SDR allocation for precautionary purposes. Large swings in commodity prices and the impact of climate change (for example flooding) are likely to increase the demand for short-term fiscal support. The mission suggested that the government reserve the RMI's recent SDR allocation - an unconditional credit line from the IMF of about \$6 million (3 percent of GDP) - for precautionary purposes. The authorities agreed and planned to explore how the terms of its use could be formally regulated.

20. The mission urged the authorities to carry out public expenditure management reforms. The government has taken steps in improving expenditure management since the amended Compact, but cash management is still based on cash rationing. The mission recommended to implement a new commitment control based management system developed with PFTAC assistance. The authorities agreed and noted that the government had scaled up its performance budgeting efforts. The mission encouraged the Ministry of Finance to become part of the exercise to strengthen its role in holding line Ministries accountable for an efficient and effective use of public funds.

\section{B. Structural Reforms to Enable Growth}

21. A vibrant private sector would contribute to economic and fiscal sustainability. The domestic economy currently depends heavily on income generated from the Compact through the consumption of goods and services, public wages, and construction projects. A larger selfsustaining business sector independent from the Compact would provide an important alternative source of income and employment. Job creation is particularly important in light of the high structural unemployment rate estimated at 30 percent.

22. The mission stressed that the government's role in supporting private sector growth should be geared towards providing an enabling environment. To support the private sector, the mission recommended the authorities focus on developing efficient infrastructure services, strengthening education and training of the workforce, and improving access to secured commercial lending. In particular, the lack of reliable electric services and the high cost of telecommunications were important obstacles to private sector development.

\section{To improve the performance of SOEs, the mission suggested that a more} transparent delineation between commercial and non-commercial services could help. Many SOEs have community service obligations, such as providing transportation or utility services to remote parts at below cost recovery tariffs. These mandates are, however, often not clearly defined and typically subsumed in the SOE's overall operating activities through crosssubsidization. This lack of transparency complicates resource planning and has contributed to weak management, underinvestment, and a continued need for subsidies and capital injections. As a result, bottlenecks in electricity provision and high costs of telecommunications, which are magnified by a small market and a high debt burden, have raised the cost of doing business and limited the development in the outer islands (for example, by limiting access to electricity or mobile banking). The mission recommended that the authorities explore the use of contractual 
arrangements in the form of community service obligations, which have been successful elements in the reform of SOEs in other countries (for example Fiji shipping company). ${ }^{7}$

24. In areas where SOEs provide purely commercial services, the mission recommended divestment. The authorities reported that they already planned to sell their stake in a hotel and were in discussions to change the public ownership of the domestic airline (AMI). Financial audit reports indicated that under current arrangements, AMI was unlikely to deliver on its community service obligations, and the mission suggested that the government should consider downsizing and divestment. The mission also recommended contracting out the management of the government's copra processing plant (Tobolar) through a competitive and transparent process.

25. The mission and the authorities agreed that the business environment remains challenging. To facilitate mortgage and commercial lending, the mission encouraged the government to step up efforts to facilitate land registration. The authorities noted that a new act on secured transactions for moveable property is now being implemented and should strengthen access to commercial credit at reduced interest costs.

\section{External Stability and Exchange Rate}

26. The authorities and staff agreed that risks to external stability were limited and the use of the U.S. dollar as currency remained appropriate given the size and remoteness of the economy. Compact related financial flows dominate external balances and result in a large current account deficit (8 percent of GDP in 2009). Staff and authorities agreed that the Compact would continue to provide a stable source of funding over the next decade, but increased debt repayment on foreign loans to the public sector (1.5 percent of GDP) would create some pressure. In the long run, the expiration of the Compact could lead to an erosion of foreign assets undermining external stability unless needed fiscal adjustments are carried out.

27. There appears to be no evidence of a price competitiveness problem (Figure 3 ). The 7 percent real appreciation in 2008 was largely reversed in the second half of 2009 as domestic prices, in particular for food, fell faster than in the U.S., its main trading partner. The authorities underscored that exports as a percentage of GDP had risen over the last decade, while they declined in most other Pacific island economies (Figure 3).

\section{Financial Sector}

28. The banking system remained profitable, but contributes little to economic growth. The banking system comprises two private banks and a public development bank, which operates outside the regulatory framework. The banking sector is primarily financed by deposits of which

\footnotetext{
${ }^{7}$ The Fiji government competitively tenders for subsidized shipping services, with private companies providing services at lower-cost to the government.
} 
65 percent is used for domestic lending. Claims on the private sector reached about 40 percent of GDP in 2009, but were largely directed towards consumer loans. Domestic investment in fixed and mobile capital remains suppressed, owing to a lack of collateral (unresolved land ownership) and poor business management. Bank profits have been solid during the last years (4.5 percent RoA) on the back of large lending spreads.

29. The mission advised the Banking Commission to take steps to limit consumer borrowing given high household indebtedness (Table 4). Consumer lending represents 75 percent of private sector lending and average household indebtedness on consumer lending is estimated at 50 percent of labor income. The mission noted the potential risks of a high debt burden to the banking system, but acknowledged that the share of non-performing loans (excluding the public bank) remained at a very low level in 2009. However, with no prudential limits on consumer borrowing, the mission supported the Commissioner's plans to modernize the Banking Act. They also encouraged the supervisor to continue strengthening monitoring capabilities, improve data collection, especially on remittances, and issue regular reports.

30. The mission urged the authorities to place the development bank under the Banking Commission's jurisdiction and end its unsecured consumer lending operations. The development bank holds 13 percent of overall banking sector assets and is heavily engaged in unsecured consumer lending. These activities are not monitored or regulated by the Banking Commission and the mission was unable to assess the quality of its loan book. The mission recommended that the bank cease lending for consumption purposes and focus instead on investment projects that face structural constraints, such as lack of collateral from unavailable land ownership titles. The Banking Commissioner agreed that the current lending practices pose a risk to the development's bank's capital base and to the government as its sole owner and that enhanced monitoring was necessary.

\section{Staff APPRAisal}

31. Achieving long-term budgetary self-reliance and sustained economic growth have become more challenging after the global crisis. Access to stable Compact grants helped advance economic development and supported a large public sector. But a recession in 2008 and falls in the value of the CTF (as a result of the global equity slump) have dimmed prospects of achieving fiscal sustainability. The scheduled decline of Compact grants and the need to replenish the CTF require a large fiscal adjustment.

32. The authorities recognize the need for reform and are looking to transform existing proposals into an actionable comprehensive adjustment program. Two local reform commissions tasked with identifying expenditure and revenue reform proposed far-reaching changes in expenditure and tax policies. These need to be unified into a comprehensive mediumterm reform program aimed at achieving lasting fiscal surpluses by streamlining the public sector and implementing a broad based tax policy reform; creating more efficient SOEs; and establishing a more business friendly environment. 
33. Securing fiscal sustainability requires a strategy that phases in spending cuts while launching a comprehensive tax reform. Consolidation needs to begin with cuts to the large public wage bill, an elimination of electricity and housing allowances, and the adjustment of electricity tariffs to cost-recovery levels. Tax reform should be comprehensive and include the replacement of the GRT with a net profit tax, the introduction of a consumption tax, an income tax reform, and a unification of tax administrations. In combination, expenditure and revenue measures should achieve a fiscal surplus of 5 percent of GDP in the medium term to secure budgetary self-sufficiency once the Compact expires.

\section{Structural reforms need to be stepped up to attain a growth path consistent with} domestic and external stability. As Compact grants decline, the economy needs to rely more on a self-propelled private sector. The government's role is to establish an enabling environment. An important priority is SOE reform to supply more reliable and cost-efficient infrastructure services, especially in the electricity and telecommunication sectors. In other areas, where SOEs conduct commercial activities, the government should divest or scale back its operations.

35. The banking sector should contribute more effectively to economic development while household indebtedness needs to be monitored. Banks primarily lend to consumers with little impact on economic development. High household indebtedness and the absence of regulatory oversight by the Banking Commission over the development bank are risks to the banking system, although commercial banks appear to be financially sound. A new secured lending act for mobile assets should facilitate commercial lending, but further efforts are needed to increase the use of land as collateral through land registration. The public development bank should be brought under the supervision of the Banking Commission. Efforts to strengthen banking supervision through improved monitoring capabilities, data collection, and increased reporting are welcome.

36. The U.S. dollar is the appropriate currency for the RMI, given the size of the economy, its close ties to the United States, and limited administrative capacity for independent monetary and exchange rate policies.

\section{The quality of official statistics, while adequate for surveillance, should be} strengthened. Data provision has improved, but limited coverage and timeliness of economic and social statistics constrain policy evaluation. Continued staff training and a new national census would aid policy planning.

38. It is recommended that the next Article IV consultation take place on the 24-month cycle. 
Figure 1. Marshall Islands: Regional Comparison of Recent Developments

Growth contracted in 2008 by more than in other countries in the region, while external and fiscal balances were comparatively unaffected owing to stable Compact related inflows. High commodity prices affected inflation more than elsewhere, but falling commodity prices have eased inflation pressures subsequently.
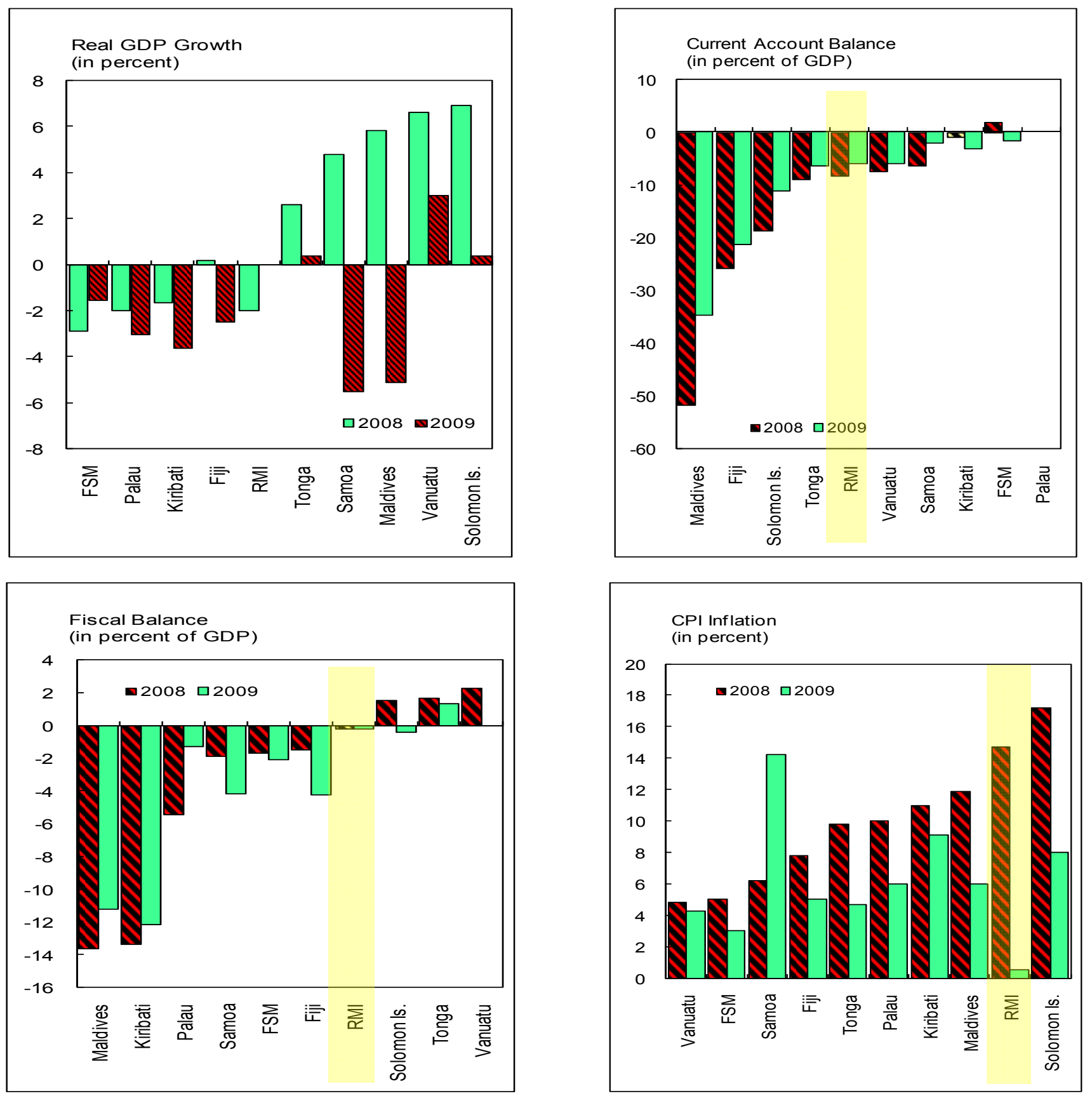

Note: RMI and FSM stand for Republic of Marshall Islands and Federated States of Micronesia, respectively.

Sources: Fund staff estimates and RMI authorities. 


\section{Figure 2. Marshall Islands: Macroeconomic Developments}

Output contracted for the first time in 10 years in 2008 despite large US compact related transfers, which dominate the current account balance. High food and energy prices led to a spike in consumer price inflation and real income losses. Despite rising spending needs, financing constraints limited the fiscal balance to a small deficit.
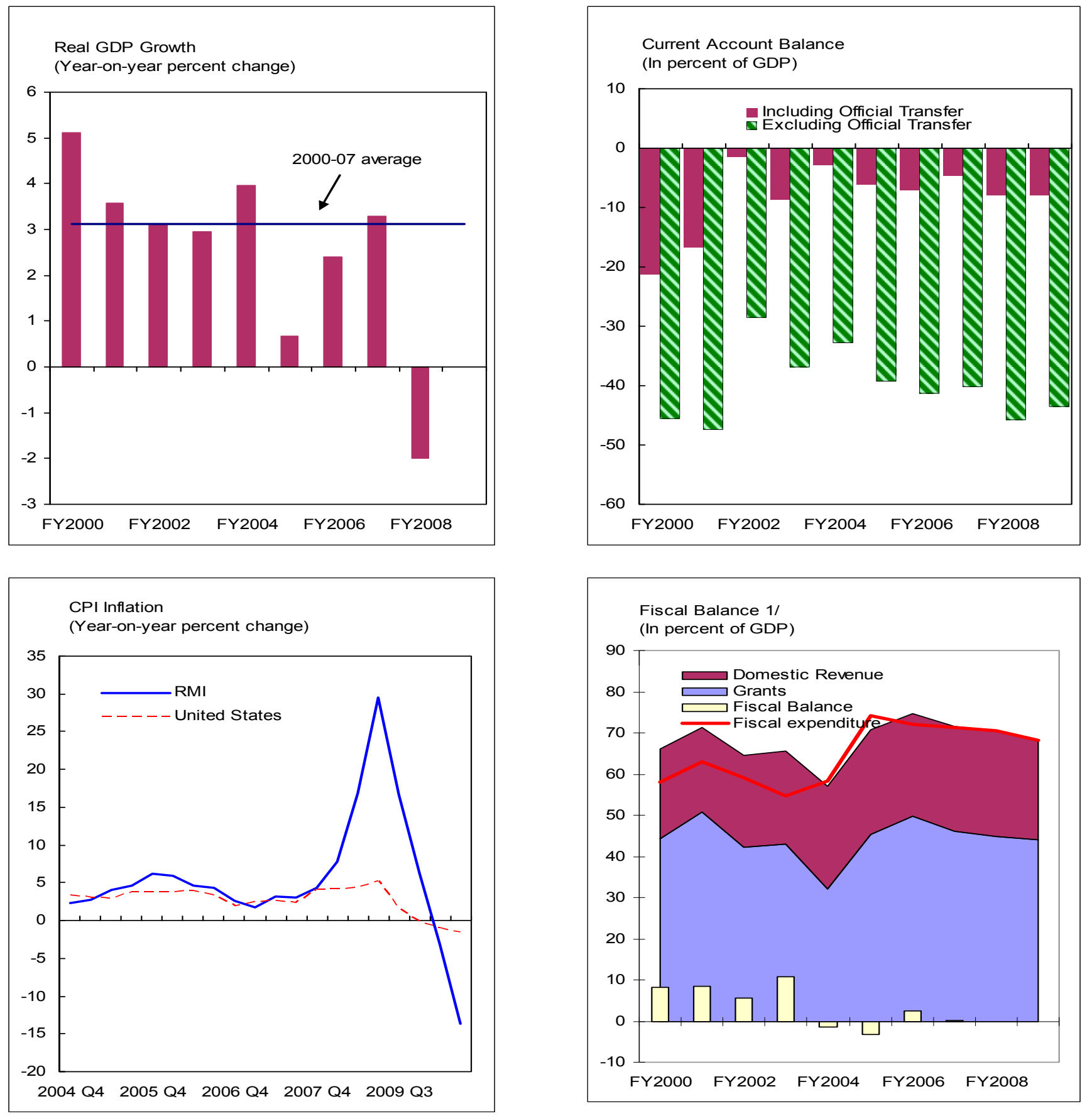

Sources: Fund staff estimates and RMI authorities.

$1 /$ Total revenue is sum of grants and domestic revenue (stacked in chart). 
Figure 3. Marshall Islands: Developments in Export Growth and the Exchange Rate 2000-08
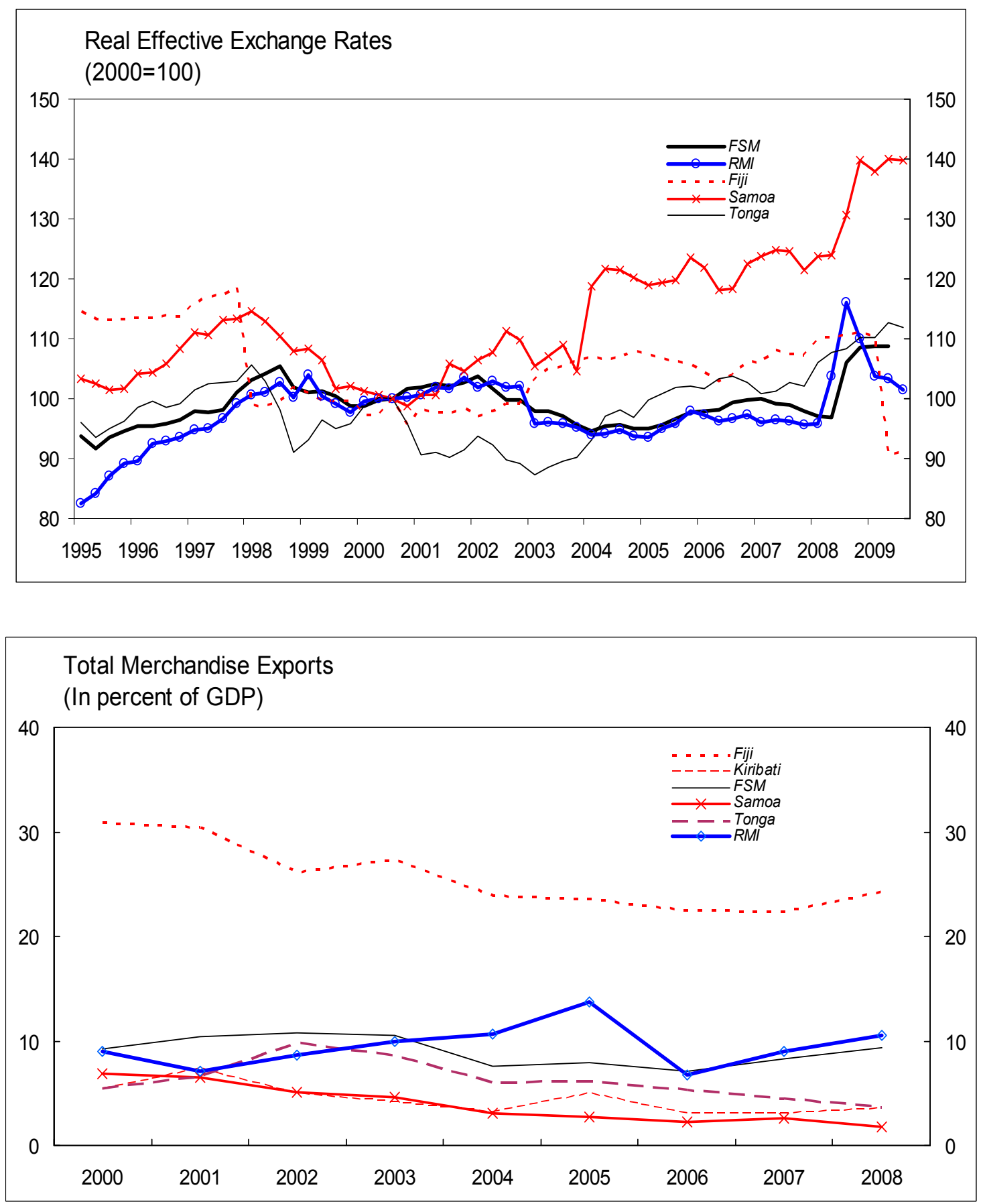

Sources: Fund staff estimates and RMI authorities. 
Table 1. Marshall Islands: Basic Data, FY2004-10 1/

Nominal GDP (2008):

Population (2008):

GDP per capita (2008):

Quota:
US\$ 152 million

53,033

US\$ 2866

SDR 3.5 million

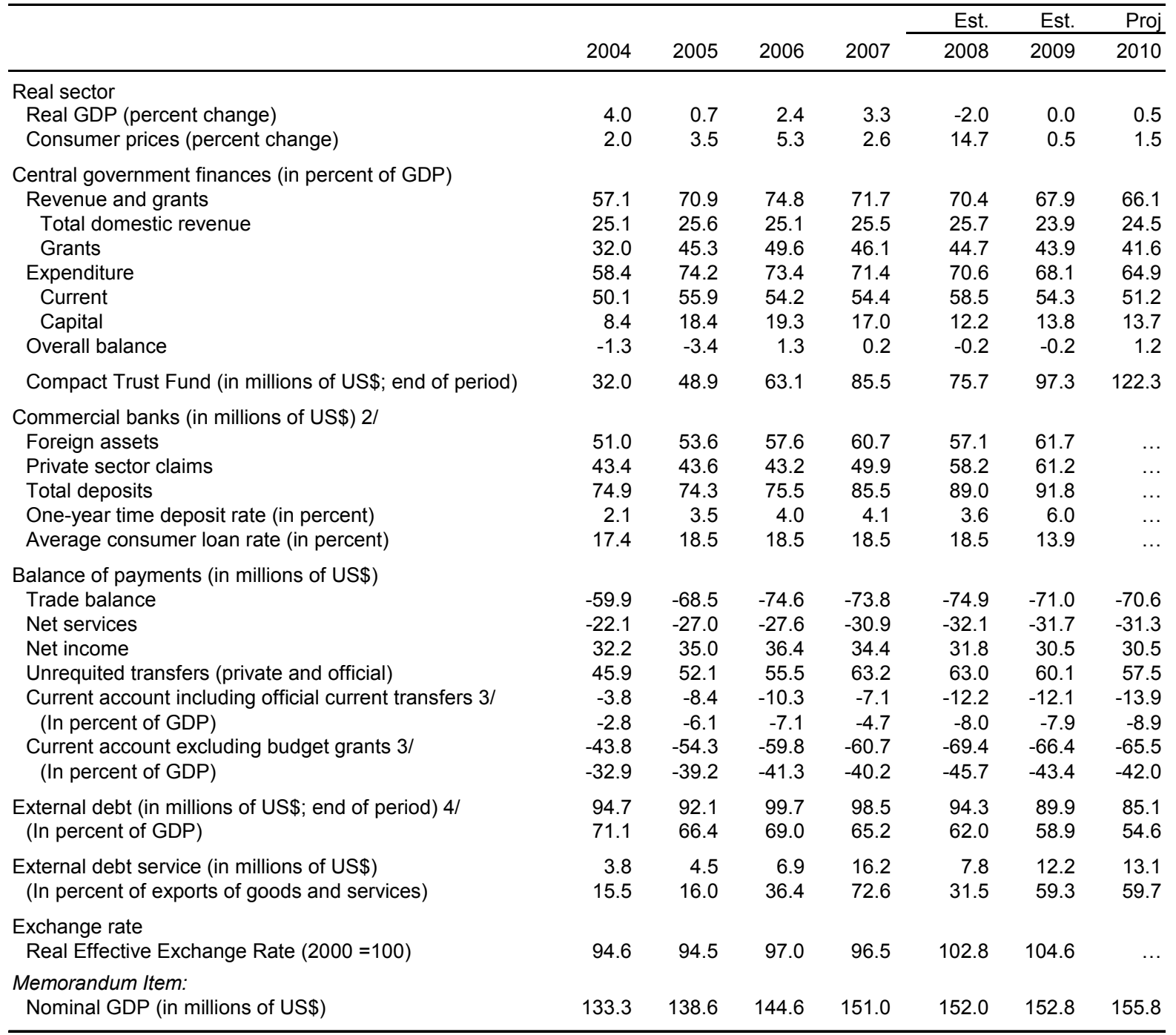

Sources: Data provided by the Marshallese authorities; and IMF staff estimates.

1/ Fiscal year ending September 30 unless otherwise stated.

2/ 2009 data are the average of three quarters.

3/ Official transfers include current transfers but exclude capital transfers and Trust Fund contributions.

4/ Includes government and government-guaranteed debts. 
Table 2. Marshall Islands: Central Government Finances, FY2004-10 1/

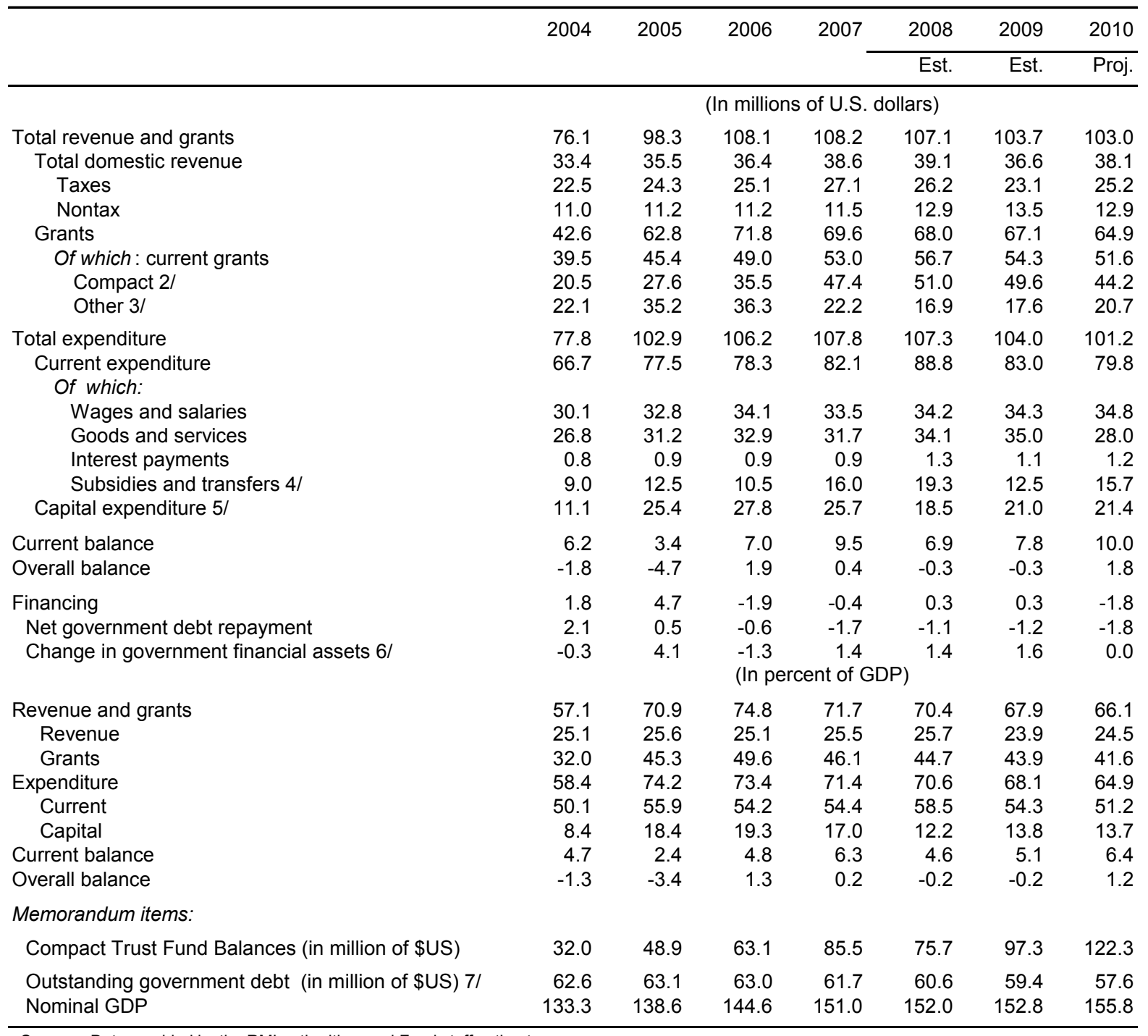

Sources: Data provided by the RMI authorities; and Fund staff estimates.

$1 /$ The fiscal year ends on September 30.

2/ Does not include Compact funds earmarked for Kwajalein rental payments and trust fund contributions.

3/ In FY05 and FY06, includes grants of $\$ 12.7$ million and $\$ 13.3$ million for the construction of the Airport.

4/ In FY2008, cash advance to the energy utility of US $\$ 6.75$ million is recorded as subsidy, and electricity consumption of US $\$ 0.76$

is deducted from goods and services.

5/ For FY05-06, capital expenditure includes additional capital projects financed by Taiwan POC and U.S. grants for the airport.

6/ Excluding Compact Trust Fund.

7/ Central government debt to ADB 
Table 3. Marshall Islands: Balance of Payments, FY2004-10 1/ (In millions of U.S. dollars)

\begin{tabular}{|c|c|c|c|c|c|c|c|}
\hline & 2004 & 2005 & 2006 & 2007 & 2008 & 2009 & 2010 \\
\hline & & & & & Est. & Est. & Proj. \\
\hline Trade balance & -59.9 & -68.5 & -74.6 & -73.8 & -74.9 & -71.0 & -70.6 \\
\hline Exports, f.o.b. & 14.2 & 19.1 & 9.7 & 13.6 & 16.0 & 14.0 & 14.8 \\
\hline Imports, f.o.b. & -74.1 & -87.6 & -84.3 & -87.3 & -90.9 & -85.0 & -85.4 \\
\hline Net services & -22.1 & -27.0 & -27.6 & -30.9 & -32.1 & -31.7 & -31.3 \\
\hline Receipts & 10.2 & 9.1 & 9.1 & 8.7 & 8.7 & 6.6 & 7.0 \\
\hline Payments & -32.3 & -36.1 & -36.7 & -39.6 & -40.7 & -38.3 & -38.4 \\
\hline Net income & 32.2 & 35.0 & 36.4 & 34.4 & 31.8 & 30.5 & 30.5 \\
\hline Receipts & 39.1 & 42.4 & 45.8 & 44.6 & 41.3 & 39.7 & 39.7 \\
\hline Of which: Labor income & 19.7 & 20.3 & 22.3 & 21.2 & 18.7 & 15.2 & 15.2 \\
\hline Payments & -6.9 & -7.4 & -9.4 & -10.3 & -9.5 & -9.1 & -9.1 \\
\hline Unrequited transfers & 45.9 & 52.1 & 55.5 & 63.2 & 63.0 & 60.1 & 57.5 \\
\hline Inflows & 49.4 & 55.6 & 59.1 & 66.9 & 66.6 & 63.7 & 61.1 \\
\hline Budget grants & 40.0 & 45.9 & 49.5 & 53.6 & 57.2 & 54.3 & 51.6 \\
\hline Compact current grants $2 /$ & 17.4 & 22.9 & 26.0 & 30.8 & 39.7 & 36.7 & 30.9 \\
\hline Other budget grants & 22.6 & 23.0 & 23.5 & 22.8 & 17.5 & 17.6 & 20.7 \\
\hline Outflows & -3.4 & -3.5 & -3.6 & -3.7 & -3.6 & -3.6 & -3.6 \\
\hline Current account including current official transfers $3 /$ & -3.8 & -8.4 & -10.3 & -7.1 & -12.2 & -12.1 & -13.9 \\
\hline (In percent of GDP) & -2.8 & -6.1 & -7.1 & -4.7 & -8.0 & -7.9 & -8.9 \\
\hline Current account excluding budget grants & -43.8 & -54.3 & -59.8 & -60.7 & -69.4 & -66.4 & -65.5 \\
\hline (In percent of GDP) & -32.9 & -39.2 & -41.3 & -40.2 & -45.7 & -43.4 & -42.0 \\
\hline Capital and financial account & -4.9 & -9.0 & 7.4 & 11.7 & 15.2 & 12.1 & 13.9 \\
\hline Official Capital Grants & 3.2 & 4.7 & 9.5 & 16.6 & 11.3 & 12.9 & 13.2 \\
\hline Trust Fund Grants & 7.0 & 9.3 & 9.0 & 9.7 & 9.7 & 10.8 & 11.4 \\
\hline
\end{tabular}

Sources: Data provided by the RMI authorities; and Fund staff estimates.

1/ Fiscal year ending September 30.

2/ Compact funding pertaining to the Kwajalein Atoll Trust Fund and Kwajalein resident and landowner compensation payments are classified as income rather than official transfers. Trust Fund contributions by the U.S. and Taiwan, POC, are regarded as capital transfers.

3/ Official transfers include current transfers but excludes capital transfers and Trust Fund contributions. 
Table 4. Marshall Islands: External Vulnerability Indicators, FY2004-10

\begin{tabular}{|c|c|c|c|c|c|c|c|}
\hline & 2004 & 2005 & 2006 & 2007 & 2008 & 2009 & 2010 \\
\hline & & & & & Est. & Est. & Proj. \\
\hline \multicolumn{8}{|l|}{ Financial indicators } \\
\hline Commercial bank deposits (12-month percent change) $1 /$ & 3.6 & -0.8 & 1.6 & 13.3 & 4.1 & $\ldots$ & $\ldots$ \\
\hline Private sector credit (12-month percent change) & 7.5 & 0.4 & -0.8 & 15.5 & 16.6 & $\ldots$ & $\ldots$ \\
\hline Foreign assets/total assets (percent) 2/ & 54.1 & 56.1 & 58.6 & 55.6 & 50.1 & 51.5 & $\ldots$ \\
\hline Nonperforming loans (in percent of total loans) 3/ & 2.0 & 2.0 & 2.0 & 2.0 & 0.8 & 1.1 & $\ldots$ \\
\hline Consumer loans (in percent of total private sector loans) & 88.8 & 87.6 & 81.5 & 77.1 & 75.4 & 74.3 & $\cdots$ \\
\hline \multicolumn{8}{|l|}{ External indicators } \\
\hline Exports (percent change) & 12.3 & 34.5 & -49.1 & 39.6 & 17.7 & -12.5 & 6.2 \\
\hline Imports (percent change) & -4.1 & 18.3 & -3.8 & 3.6 & 4.0 & -6.5 & 0.5 \\
\hline \multicolumn{8}{|l|}{ Current account balance (percent of GDP) } \\
\hline Including official current transfers & -2.8 & -6.1 & -7.1 & -4.7 & -8.0 & -7.9 & -8.9 \\
\hline Excluding official transfers & -32.9 & -39.2 & -41.3 & -40.2 & -45.7 & -43.4 & -42.0 \\
\hline Capital and financial account balance (percent of GDP) & -3.7 & -6.5 & 5.1 & 7.7 & 10.0 & 7.9 & 8.9 \\
\hline Of which: FDI (in millions of U.S. dollars) & 0.6 & 2.7 & 1.9 & 8.4 & 5.1 & 5.1 & 5.1 \\
\hline Total external debt (percent of GDP) & 71.1 & 66.4 & 69.0 & 65.2 & 62.0 & 58.9 & 54.6 \\
\hline Total external debt (in percent of exports of goods and services) & 388.1 & 326.2 & 530.1 & 441.6 & 382.6 & 436.1 & 388.7 \\
\hline External debt service (in percent of exports of goods and services) & 15.5 & 16.0 & 36.4 & 72.6 & 31.5 & 59.3 & 59.7 \\
\hline
\end{tabular}

Sources: Data provided by the RMI authorities; and Fund staff estimates.

$1 /$ The large increase in financial indicators in 2007 reflect a government guaranteed loan to energy company.

2/ 2009 is average of three quarters.

3/ Defined as loans with arrears in excess of 90 days. 2009 is average of three quarters. 
Table 5. Marshall Islands: Medium-term Scenario, FY2006-14 1/

\begin{tabular}{|c|c|c|c|c|c|c|c|c|c|}
\hline & 2006 & 2007 & 2008 & 2009 & 2010 & 2011 & 2012 & 2013 & 2014 \\
\hline & & & & $\overline{\text { Est. }}$ & \multicolumn{5}{|c|}{ Projections } \\
\hline \multicolumn{10}{|l|}{ Real sector } \\
\hline Real GDP (percent change) & 2.4 & 3.3 & -2.0 & 0.0 & 0.5 & 1.5 & 1.5 & 1.5 & 1.5 \\
\hline Consumer prices (percent change) & 5.3 & 2.6 & 14.7 & 0.5 & 1.5 & 2.0 & 2.5 & 2.5 & 2.5 \\
\hline \multicolumn{10}{|l|}{ Central government finance (in percent of GDP) } \\
\hline Revenue and grants & 74.8 & 71.7 & 70.4 & 67.9 & 66.1 & 64.8 & 63.5 & 60.8 & 60.3 \\
\hline Total domestic revenue & 25.1 & 25.5 & 25.7 & 23.9 & 24.5 & 24.7 & 25.0 & 25.1 & 25.0 \\
\hline Grants & 49.6 & 46.1 & 44.7 & 43.9 & 41.6 & 40.1 & 38.5 & 35.7 & 35.3 \\
\hline Expenditure & 73.4 & 71.4 & 70.6 & 68.1 & 64.9 & 63.3 & 62.0 & 59.3 & 58.8 \\
\hline Current 2/ & 54.2 & 54.4 & 58.5 & 54.3 & 51.2 & 50.1 & 49.3 & 47.1 & 46.8 \\
\hline Capital & 19.3 & 17.0 & 12.2 & 13.8 & 13.7 & 13.2 & 12.7 & 12.2 & 12.0 \\
\hline Overall balance & 1.3 & 0.2 & -0.2 & -0.2 & 1.2 & 1.5 & 1.5 & 1.5 & 1.5 \\
\hline Compact Trust Fund (in millions of US\$; end of period) & 63.1 & 85.5 & 75.7 & 97.3 & 122.3 & 145.0 & 169.6 & 196.4 & 225.5 \\
\hline \multicolumn{10}{|l|}{ Balance of payments (in millions of US\$) } \\
\hline Trade balance & -74.6 & -73.8 & -74.9 & -71.0 & -70.6 & -70.2 & -69.3 & -66.9 & -67.0 \\
\hline Net services & -27.6 & -30.9 & -32.1 & -31.7 & -31.3 & -31.2 & -30.8 & -29.6 & -29.6 \\
\hline Net income & 36.4 & 34.4 & 31.8 & 30.5 & 30.5 & 30.5 & 30.6 & 31.0 & 31.3 \\
\hline Private and official transfers & 55.5 & 63.2 & 63.0 & 60.1 & 57.5 & 57.5 & 57.6 & 55.5 & 57.0 \\
\hline \multirow{2}{*}{$\begin{array}{l}\text { Current account including official current transfers } 3 / \\
\text { (In percent of GDP) }\end{array}$} & -10.3 & -7.1 & -12.2 & -12.1 & -13.9 & -13.4 & -11.9 & -10.0 & -8.3 \\
\hline & -7.1 & -4.7 & -8.0 & -7.9 & -8.9 & -8.3 & -7.1 & -5.7 & -4.6 \\
\hline \multirow{2}{*}{$\begin{array}{l}\text { Current account excluding official transfers 3/ } \\
\text { (In percent of GDP) }\end{array}$} & -59.8 & -60.7 & -69.4 & -66.4 & -65.5 & -64.8 & -63.3 & -59.2 & -58.7 \\
\hline & -41.3 & -40.2 & -45.7 & -43.4 & -42.0 & -40.2 & -37.7 & -33.9 & -32.3 \\
\hline \multirow{2}{*}{$\begin{array}{l}\text { External debt (in millions of US\$; end of period) 4/ } \\
\text { (In percent of GDP) }\end{array}$} & 99.7 & 98.5 & 94.3 & 89.9 & 85.1 & 80.0 & 74.4 & 68.8 & 63.1 \\
\hline & 69.0 & 65.2 & 62.0 & 58.9 & 54.6 & 49.6 & 44.3 & 39.4 & 34.7 \\
\hline \multirow{2}{*}{$\begin{array}{l}\text { External debt service (in millions of US\$) } \\
\text { (In percent of exports of goods and services) }\end{array}$} & 6.9 & 16.2 & 7.8 & 12.2 & 13.1 & 12.4 & 13.0 & 13.0 & 12.9 \\
\hline & 36.4 & 72.6 & 31.5 & 59.3 & 59.7 & 53.0 & 51.5 & 47.8 & 44.0 \\
\hline
\end{tabular}

Sources: Data provided by the RMI authorities; and Fund staff estimates.

1/ Fiscal year ending September 30.

2/ In FY2008, cash advance to the energy utility of US $\$ 6.75$ million is recorded as subsidy and electricity consumption of US $\$ 0.76$

is deducted from goods and services.

3/ Official transfers include current transfers but exclude capital transfers and Trust Fund contributions.

4/ Government and government-guaranteed debt only. 


\section{APPENDIX: MARSHALL ISLANDS-LONG-TERM FISCAL SUSTAINABILITY}

\section{After the completion of the first Compact, the RMI signed an amended} Compact agreement in $\mathbf{2 0 0 4}$ with a 20-year tune horizon. The amended Compact introduced a new fiscal framework by creating a Compact Trust Fund (CTF) and by earmarking grants to specific sectors (infrastructure 30-50 percent; remainder for education, health care, environment, capacity building, and private sector development). The main purpose of the trust fund is to create an income stream to replace the Compact grants after 2023, when the agreement expires.

2. This note updates the IMF's long-term fiscal projections as developed in 2008 IMF Selected Issues paper and assesses the implications of the 2008 global equity market corrections and of the delays in fiscal adjustment. The note defines fiscal sustainability as an 2023 CTF asset level that would create an income stream large enough to replace the Compact grants without eroding the real value of the assets, as required under the Trust Fund agreement.

\section{Under the baseline scenario, the CTF's income balance would not be large} enough to cover Compact grants in 2024. This scenario assumes that the government maintains a fiscal surplus of about $1 \frac{1}{2}$ percent of GDP throughout mainly to service public debt repayment obligations. GDP growth gradually decelerates to 1.2 percent as foreign grant assistance declines while private sector growth remains sluggish, and declines to 0.5 percent after the Compact agreement expires. The rate of return on CTF assets in 2009 is estimated to be about 9.4 percent and projected to stay at about this level in 2010 and decline to 6 percent thereafter. Compact grants are projected to reach $\$ 45.3$ million in 2023 . Given the terms of

\section{Marshall Islands Compact Trust Fund (CTF): Baseline Versus the Policy Action Scenario}

\begin{tabular}{lcc}
\hline & $\begin{array}{l}\text { Baseline } \\
\text { (In millions of U.S. Dollars) }\end{array}$ \\
\hline CTF in 2023 & 617.4 & $\begin{array}{c}\text { Policy Action } \\
\text { CTF earnings in } 2024\end{array}$ \\
Earnings available for withdrawal & 37.0 & 44.2 \\
Compact grants in 2023 & 23.3 & 26.2 \\
Compact grants net of fiscal surplus & 45.3 & 45.3 \\
Surplus (+) or Shortfall (-) 1/ & 45.3 & 26.2 \\
\hline
\end{tabular}

1/ Calculated as earnings available for withdrawal minus Compact grants in 2023 net of fiscal surplus Source: IMF staff calculations. 
the Compact agreement and without additional contributions, the fund's investment earnings are projected to be $\$ 37$ million in 2024 . In order to preserve the real value of the fund, the RMI government would only be able to withdraw $\$ 23.3$ million, leaving a gap of US\$2 2 million ( $\$ 10.5$ percent of GDP see text table). Therefore, in the baseline scenario, the RMI government either would need to erode the real value of the CTF or would face a large budgetary shortfall.

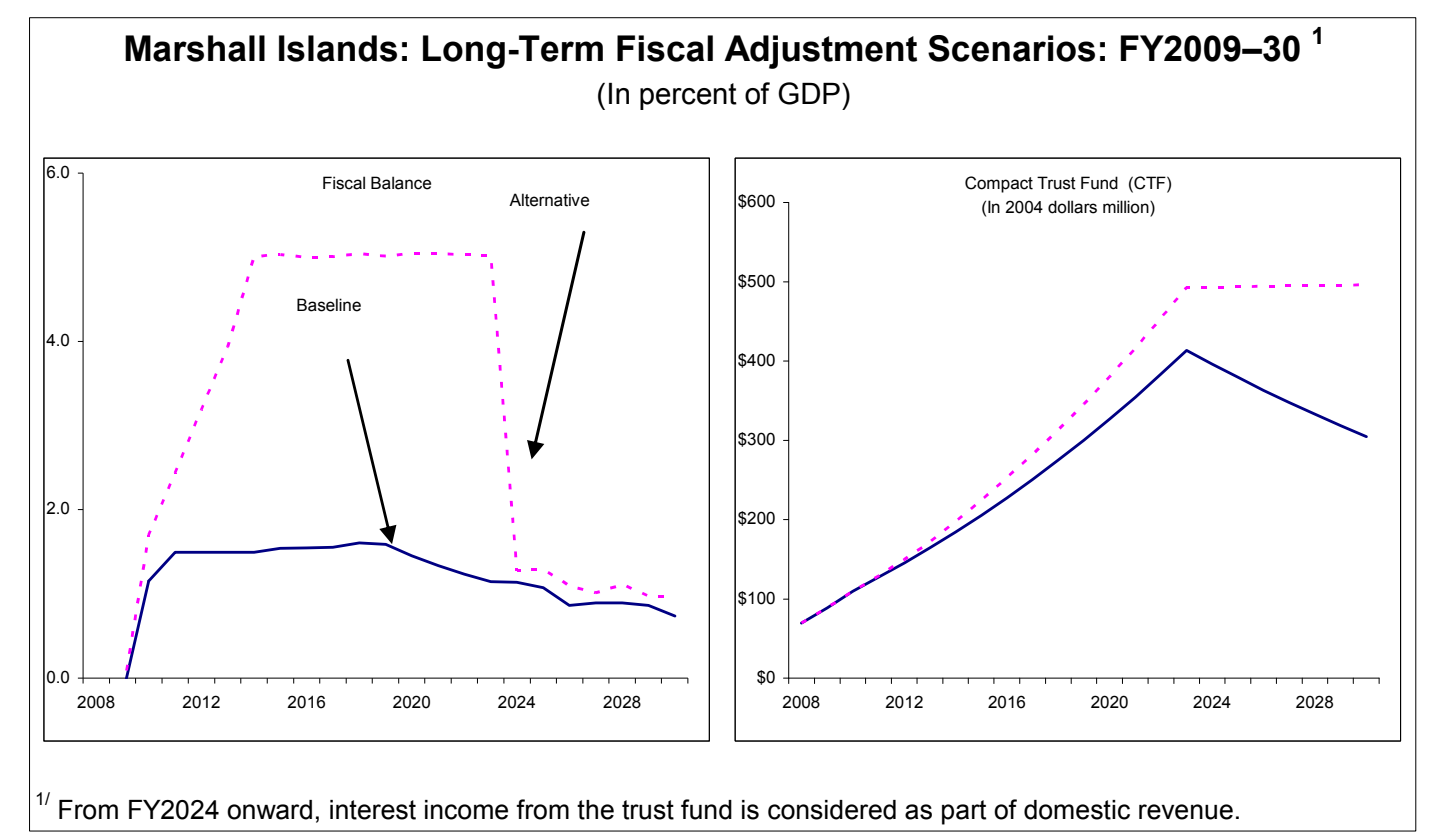

4. While higher returns can help achieve fiscal sustainability, obtaining such high returns over the entire period is not realistic. The baseline assumes a relatively conservative investment strategy with average nominal rate of return of 6 percent. Higher returns would be possible with a more aggressive investment strategy, albeit at the cost of higher risks. For example, if the average rate of return were 8.2 percent, the shortfall would be eliminated. This rate of return is 0.2 percentage point higher than the equivalent estimate from the 2008 Article IV consultation.

5. Fiscal sustainability can be achieved through significant fiscal consolidation and structural reforms to boost private sector growth. In an alternative policy scenario, the government would gradually shift public finances into surplus (by about one percent of GDP each year) and channel the generated savings into the CTF. Over the medium-term, roughly half of the adjustment would come from tax revenues and the other half from reductions in current expenditures. In parallel, structural reforms are assumed to boost real growth to 2 percent. This scenario continues to assume a nominal rate of return to the CTF of 6 percent. With these assumptions, fiscal sustainability would be achieved by progressively building a fiscal surplus to reach around 5 percent of GDP in 2014. The surplus would stay at this level 
until 2024 then decline to about 1 percent. Together with the additional earnings resulting from higher balances, the fiscal surplus would eliminate the revenue shortfall (see text table). The required adjustment in the 2008 IMF Selected Issues paper was less, at about 3.5 percent of GDP. The difference mainly reflects the significant declines in the value of CTF assets during 2008 .

6. With fiscal consolidation, the government would be able to obtain a constant revenue stream to finance its expenditures. In particular, under the alternative policy scenario, the government keeps capital spending constant throughout. However, current expenditures would be adjusted so that total revenues could both finance total expenditures and generate a sustainable assets level in the CTF. The reduction in the fiscal surplus in 2024 would not constitute a fiscal stimulus. Rather it would reflect the switch from a grant to a CTF income based funding system, as foreseen under the Compact. In 2024, there is no need to save additional amounts to accumulate the CTF, total revenues including interest income obtained from the CTF, are only used to finance overall yearly budget expenditures eliminating the need for continued surpluses. ${ }^{1}$

\footnotetext{
${ }^{1}$ After 2024, the government still runs an overall surplus to service external debt.
} 


\section{INTERNATIONAL MONETARY FUND \\ REPUBLIC OF THE MARSHALL ISLANDS \\ Staff Report for the 2009 Article IV Consultation-Informational Annex}

Prepared by Asia and Pacific Department

(In consultation with other departments)

January 15, 2010

Contents

Page

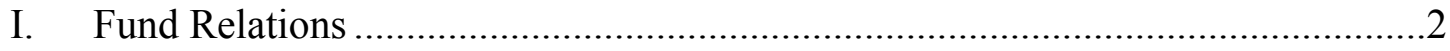

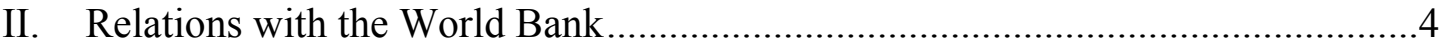

III. Relations with the Asian Development Bank ............................................6

IV. Relations with the Pacific Financial Technical Assistance Centre .......................8

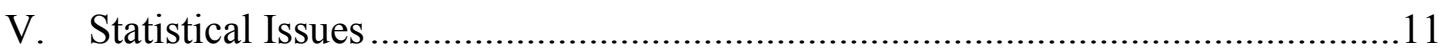




\section{ANNEX I. MARSHALl ISLANDS: FUND RELATIONS}

(As of November 30, 2009)

I. Membership Status: Joined May 21, 1992;

Article VIII

II. General Resources Account: SDR Million

Percent Quota

Quota 3.50

100.00

Fund holdings of currency

3.50

100.00

Reserve position in Fund

0.00

0.01

III. SDR Department:

SDR Million

Percent Allocation

Net cumulative allocation

100.00

Holdings

100.00

IV. Outstanding Purchases and Loans: None

V. Financial Arrangements: None

VI. Projected Obligations to Fund: None

VII. Exchange Rate Arrangements:

The U.S. dollar is legal tender and the official currency. The Marshall Islands maintains an exchange system that is free of restrictions on the making of international payments and transfers for current and capital transactions.

VIII. Article IV Consultation:

The Marshall Islands is on a 24-month consultation cycle. The 2009 Article IV Consultation discussions were held during November 10-18, 2009. The Executive Board discussed the staff report and concluded the consultation on February 3, 2010.

IX. Technical Assistance: As indicated below.

X. Resident Representative: None. 
MARShall Islands: TeChNiCAL ASSISTANCE FROM HEADQUARTERS, 1992-2009'1

\begin{tabular}{|l|l|r|}
\hline Source & \multicolumn{1}{|c|}{ Purpose } & Time of Delivery \\
FAD & Assess technical assistance needs in fiscal management & August 1992 \\
LEG & Banking legislation & March 2003 \\
MAE & Assess technical assistance needs in banking supervision & August 1992 \\
MAE & Panking Commissioner & October 1994- \\
MAE & Assessment of off-shore financial center & Jug6 \\
MFD & Follow-up OFC/AML/CFT & March 2000 \\
MFD & Bank supervision & May 2002 \\
MFD & Bank supervision & February 2004 \\
STA & $\begin{array}{l}\text { Assess technical assistance needs for the development of } \\
\text { economic statistics }\end{array}$ & March 2004 \\
\hline
\end{tabular}

\footnotetext{
${ }^{1}$ Technical assistance has been provided through PFTAC since 2005 - see Annex IV.
} 


\section{ANNEX II. MARShall ISLANDS: Relations With THE WORLd BANK ${ }^{1}$}

Since becoming a World Bank Group member in May 1992, the Marshall Islands received a grant of $\$ 150,000$ from the Institutional Development Fund. The fund was approved in May 1993 to assist the Presidential Committee on the rationalization of the public service. The prepared report detailing an action plan for public sector reform was accepted by the government, and the recommendations were implemented in joint assistance with the United Nations Development Program (UNDP). On June 12, 2007, the World Bank Board of Executive Directors approved $\$ 9.5$ million provided by the Global Environment Facility to fund renewable energy electricity supplies for rural communities in Marshall Islands, among other Pacific Island countries. The project in the Marshall Islands is led by the International Finance Corporation (IFC), the World Bank's private sector arm. IFC is currently advertising for a 5-year term Management Consultant to assist with the implementation of the project.

As part of a broader effort to deepen engagement with the Republic of the Marshall Islands and other World Bank Group members in the North Pacific, the World Bank has recently assigned a Senior Economist based in Washington, D.C. to work with the government and to outline a substantive program of technical assistance. In addition, the World Bank is also exploring a artnership with the Overseas Development Institute (ODI), a leading independent think-tank on development and humanitarian issues based in the United Kingdom, under which the Institute might assign postgraduate economists under its Fellowship scheme. Fellows would provide valuable in-country support the public sectors of the Marshall Islands and other clients in the North Pacific and serve as a point of contact with the World Bank Group and other development partners throughout the fellowship period. The Director of the ODI Fellows program is expected to undertake a scoping mission to the North Pacific in early 2010.

In March 2009, senior World Bank management held consultations with the government and World Bank staff participated in November 2009 in the International Monetary Fund (IMF) Article IV consultation mission. Acknowledging the impacts of the food, fuel and global financial crises, the World Bank is currently responding to government requests for technical assistance with the objective of reducing the country's vulnerability to petroleum price volatility, improving energy efficiency, and increasing use of renewable energy and access to reliable energy supplies. In September 2009, World Bank Technical Staff also participated in an analysis of the performance and prospects for the Marshalls Energy Company (MEC), the state-owned enterprise that provides generation and distribution services on Majuro. In recognition of this increased demand for development assistance in the Marshall Islands in the current environment - the scope of which is currently constrained by the country's IBRD status - the World Bank is also exploring the possibility that the country could obtain exceptional access to concessional IDA resources.

- $\quad$ Doing Business 2010: Comparing Regulation in 183 Countries, September 2009;

\footnotetext{
${ }^{1}$ Prepared by World Bank staff (East Asia Pacific).
} 
- Opportunities to Improve Social Services: Human Development in the Pacific Islands, July 2007;

- $\quad$ At Home and Away - Expanding Job Opportunities for Pacific Islanders through Labour Mobility, August 2006;

- $\quad$ The Pacific Infrastructure Challenge, 2006; and

- $\quad$ Not If, But When: Adapting to Natural Hazards in the Pacific Islands Region, 2006. 


\section{AnNex III. Marshall ISlands: Relations With the ASIAN DeVelopMent Bank ${ }^{1}$}

The country strategy of the Asian Development Bank (AsDB) for the Republic of the Marshall Islands (RMI) is set out in "Pacific Strategy 2005 to 2009: Responding to the Priorities of the Poor." The country strategy has been updated regularly in a participatory manner engaging representatives of civil society as well as the government. A new AsDB's strategy for the RMI covering the period 2010-12 will be available in early 2010 . The report lays out planned technical assistance (TA) projects and focuses on raising public sector productivity as a means to improve the delivery of public services, enhance the environment for private sector development, and boost governance. The strategy fosters greater community participation in development and concentrates on achieving measurable results in the short term.

Since joining the AsDB in April 1990, the RMI has received 11 loans totaling \$78.1 million. AsDB loans have covered education, fisheries, health, water, and transport, and support for public sector reform and structural adjustment (see table). One loan assisted emergency typhoon rehabilitation. Since 2002, AsDB's program for the RMI has increasingly focused on grant TA rather than loans. All AsDB loans to the RMI have now been closed. As of end December 2008 TA grants totaling almost $\$ 18.9$ million for 46 TA projects have been approved. These comprise both project preparatory and advisory TA. The TA program has covered a wide range of sectors and issues from support to AsDB loans to building capacities in development banking, tourism management, environmental protection, economic policy formulation, as well as in privatizing state-owned enterprises, developing the private sector, and reforming the civil service.

In November 2004, the AsDB approved an advisory technical assistance program to improve the environment for private sector development. Continued assistance to the Land Registration Authority, the establishment of a Secure Transactions Agency, a study of the status and trends of land tenure, and continuation of the administrative barriers working group are all components of this TA. Its completion is scheduled for December 2009.

In May 2006, the AsDB approved an advisory technical assistance program to support the collaborative design and society-endorsed delivery of initial pilot personnel performance audits for the Ministry of Education. The intent was to improve employee productivity. The TA also supported more effective delivery of youth-at-risk welfare services through continued outsourcing to civil society organizations. The TA was completed in May 2008.

In December 2006, a $\$ 150,000$ grant from the MfDR Cooperation Fund was approved for improving independent policy results-based management. This initiative aims to strengthen the

\footnotetext{
${ }^{1}$ Prepared based on input from the AsDB staff.
} 
RMI's statistics generation and analytical capacities to monitoring and manage country development results. This will provide support through to 31 December 2009.

Recently, the AsDB provided support for domestic public sector reform initiatives by deploying technical experts to address human resource, energy, and public finance matters. Such support has been provided in close coordination with other donor partners, including the United States, IMF/PFTAC, Australia, Japan, and European Union.

Table 1: Asian Development Bank

Loans to the Republic of the Marshall Islands by Sector

(In millions of U.S. dollars; as of December 31, 2008)

\begin{tabular}{lrr}
\hline Sector & Number & Amount \\
\hline & & \\
Agriculture and Natural & 1 & 6.95 \\
Resources & 2 & 14.83 \\
Education & 0 & 0.00 \\
Energy & 0 & 0.00 \\
Finance & 1 & 5.70 \\
Health, Nutrition, and Social Protection & 0 & 0.00 \\
Industry and Trade & 3 & 24.00 \\
Law, Economic Management, and Public Policy & 1 & 7.00 \\
Transportation and Communication & 2 & 9.90 \\
Water Supply, Sanitation, and Waste Management & 2 & 9.75 \\
Multisector loans & 12 & 78.13 \\
$\quad$ Total & & \\
Memorandum Item: & & 18.91 \\
Technical Assistance & 46 & \\
\hline
\end{tabular}




\section{Annex IV. Marshall Islands: Relations With the PaCific Financial TeChnical Assistance Centre ${ }^{1}$}

The Pacific Financial Technical Assistance Centre (PFTAC)'s assistance to the RMI during the past years has focused on financial supervision, public expenditure management, and tax administration policy through numerous missions, which RMI officials attended regional seminars and workshops. PFTAC also organized one secondment for staff in banking supervision.

\section{Public Financial Management}

In the last three years PFM activity in RMI has increased significantly. A peripatetic consultant was fielded by PFTAC to work on fiscal forecasting and again in June 2008 for one final visit to anchor the system and provide training. A cash management manual was developed by PFTAC and training provided on its operation in early 2007. A peripatetic consultant has since provided training on the operation of the system to line ministries and visited RMI in January 2008, along with the PFTAC advisor, to provide further training and to review the system. The PFTAC advisor visited RMI again in May 2009 to provide training. PFTAC is meanwhile developing a commitment control manual for RMI and a commitment control system may be installed, and training provided once the government's feedback of the draft commitment control manual is received.

PFTAC also carried out an assessment of the IFMIS systems in RMI in December 2009 with a view to recommend next steps to improve the operation of the system.

\section{Tax Administration and Policy}

In 2008, the Minister of Finance set up the Tax and Revenue Reform Modernization Commission (TRRMC) to make recommendations to reform the revenue collection system and to strengthen the capabilities and effectiveness of the Division of Revenue and Taxation (DRT). The TRRMC is required to make recommendations to the Minister of Finance early in 2010. The PFTAC Revenue Advisor is an advisor to the TRRMC

\footnotetext{
${ }^{1}$ Prepared based on the input from the PFTAC staff. PFTAC, which is located in Suva, Fiji, is a multi-donor TA institution financed by the IMF, AsDB, AusAID, NZAID, Japan, and Korea, with the IMF as the Executing Agency. The Centre's aim is to build skills and institutional capacity for effective economic and financial management that can be sustained at the national level. Member countries are: Cook Islands, Federated States of Micronesia, Fiji, Kiribati, Marshall Islands, Nauru, Niue, Palau, Papua New Guinea, Samoa, Solomon Islands, Tokelau, Tonga, Tuvalu, and Vanuatu.
} 
PFTAC has carried out five missions since 2007. The earlier missions focused on revenue administration including (a) the amalgamation of local and central government revenue administrations, and (b) the setting up of the TRRMC.

The most recent mission in September 2009 made revenue policy (reform) recommendations for the TRRMC to consider when making its report and recommendations to the Minister of Finance. The authorities have recently shown renewed interest in tax reforms and, if requested, PFTAC will provide resources to assess the revenue system, design a tax administration modernization plan, and review exemptions.

A short PFTAC mission took place in December 2007 and provided short-term revenue enhancing measures including integration of local and national government taxes, as well as discussions about longer-term revenue reforms to address the narrow tax base and low levels of compliance.

\section{Financial Sector Regulation and Supervision}

Following a mission by a peripatetic advisor in April 2006, the PFTAC advisor visited RMI in May 2006 and recommended that the Banking Commission expand the scope of its on-site examinations of banks to include operational and liquidity risk management. Also in 2006, the Advisor provided comments to the Commission on an application to establish a new bank in Majuro. In March 2007, the Advisor assisted the Banking Commission to conduct an onsite examination covering these areas and AML/CFT compliance at one bank. The Advisor also provided the Commission with draft prudential guidelines on operational and liquidity risk, as well as a critique of the Commission's statistical returns.

In November 2007, the Advisor assisted the Commission in conducting an on-site examination at one bank to follow up on actions taken to resolve concerns arising from the March 2007 AML/CFT examination. PFTAC also arranged and provided financial assistance in 2007 for the Assistant Banking Commissioner to be attached to the Hawaiian bank supervisory authority to participate in an on-site examination. At the request of the Commissioner, the Advisor visited the Commission in July 2008. The focus of the mission was to strengthen the capacity of the authorities to conduct off-site surveillance of banks with a number of revisions recommended to the prudential reporting requirements for banks and expansion of the off-site monitoring database. The mission also included training in the analysis of financial statements to assess a borrower's credit risk.

At the request of the Commission, a follow-up visit is planned for late-January 2010 to assist and provide training to the Commission in conducting a full-scope CAMELS examination and the application of financial statement analysis in assessing credit risk and asset quality. 


\section{Economic and Financial Statistics}

The Economic Policy, Planning and Statistics Office (EPPSO) received significant training since 2005 on balance of payments and national accounts statistics, including through participation on a PFTAC regional national accounts statistics course conducted in Pohnpei, Federated States of Micronesia in 2006. Despite the extensive training, these statistics continued to be compiled by external consultants. The previous PFTAC Statistics Advisor provided some technical backstopping to the national accounts consultant, and in July 2007 visited RMI to assist with the improvement and compilation of their Balance of Payments (BOP) statistics. The mission was carried out in conjunction with the two consultants who are funded by the U.S. Department of Interior to update the Annual Compact Report.

In November 2008, the current PFTAC Advisor undertook a joint BOP and national accounts statistics mission to RMI to continue development work on BOP and NA sources and methods, as well as to assist in updating BOP and NA estimates. The EPPSO counterpart left in early 2009 and there is currently no statistics staff at EPPSO. As a result, two consultants funded by the U.S. Department of Interior visited RMI in mid-2009 and updated the BOP and national accounts statistics for inclusion in the Annual Compact Report. 


\section{ANNEX V. MARSHALl ISLANDS-STATISTICAL ISSUES \\ As of December 03, 2009}

\section{ASSESSMENT OF DATA ADEQUACY FOR SURVEILLANCE}

General: Data provision has some shortcomings, but is broadly adequate for surveillance. The authorities willingly share available data, yet shortcomings exist in most areas, most notably in national accounts, balance of payments, banking, and government finance statistics. An Economic Policy, Planning, and Statistics Office (EPPSO) was established in February 2003 to collect and disseminate economic statistics; however, it still lacks sufficient qualified staff and capacity to produce timely data. The publication of the Quarterly Bulletin of Statistics was resumed in June 2003, containing mainly CPI data. Other quarterly and monthly data are not published or transmitted to the Fund. Extensive Fund technical assistance has been provided from headquarters and the Pacific Financial Technical Assistance Centre (PFTAC). Two consultants funded by the U.S. Department of Interior updated the BOP and national accounts statistics for inclusion in the Annual Compact Report in mid2009. The authorities have expressed an interest in participating in the IMF's General Data Dissemination System (GDDS).

National Accounts: National income accounts from FY1997-FY2008 have been prepared by U.S. funded consultants. Shortcomings with these data remain, especially with the deflators to compute real GDP, operating surpluses, and employment data sources. Although these estimates represent an improvement, these shortcomings preclude accurate and timely evaluation of savings-investment balances.

Price statistics: A quarterly consumer price index (CPI), rebased to 2003 and utilizing expenditure weights derived from information from a 2002 Household Income and Expenditure Survey, is adequate for surveillance purposes.

Government finance statistics: Fiscal data are regularly compiled for budget control, and with the help of consultants, they are consolidated into a format suitable for analysis.

Monetary statistics: A reporting system for domestic banking institutions, based on a monthly reporting system was developed in 1993 with STA technical assistance. Even though data are reported by banks to the Banking Commissioner, they are not published or reported to the Fund. Tables on basic balance sheet items as well as income and expenses are prepared for inclusion in the Annual Compact Report, however further improvements and details would prove useful in surveillance.

Balance of payments: Compilation of balance of payments data has improved recently with technical assistance from PFTAC. Nonetheless, the timely and accurate compilation of import statistics has been hampered by backlogs in data entry and inappropriate classification and coding issues. With no compulsory reporting, export statistics are incomplete. Only limited data are available on services, factor income, and there are no reliable data on remittances and private financial flows. These shortcomings impart a high degree of uncertainty to any analysis of external sector developments.

\section{DATA STANDARDS AND QUALITY}

The RMI does not participate in the IMF's GDDS. No data ROSC is available.

\section{REPORTING TO STA}

No data are reported to STA for dissemination in Fund statistical publications. 


\section{MARSHALL ISLANDS: TABLE OF COMMON INDICATORS REQUIRED FOR SURVEILLANCE} As OF DECEMBER 16, 2009

\begin{tabular}{|c|c|c|c|c|c|}
\hline & $\begin{array}{c}\text { Date of } \\
\text { latest } \\
\text { observation }\end{array}$ & $\begin{array}{l}\text { Date } \\
\text { received }\end{array}$ & $\begin{array}{c}\text { Frequency } \\
\text { of } \\
\text { Data }^{8}\end{array}$ & $\begin{array}{l}\text { Frequency } \\
\text { of } \\
\text { Reporting }^{8}\end{array}$ & $\begin{array}{l}\text { Frequency of } \\
\text { publication }^{8}\end{array}$ \\
\hline Exchange Rates & Oct. 2009 & Dec. 2009 & M & M & M \\
\hline $\begin{array}{l}\text { International Reserve Assets and Reserve Liabilities of } \\
\text { the Monetary Authorities } 1\end{array}$ & NA & NA & NA & NA & NA \\
\hline Reserve/Base Money & NA & NA & NA & NA & NA \\
\hline Broad Money & NA & NA & NA & NA & NA \\
\hline Central Bank Balance Sheet & NA & NA & NA & NA & NA \\
\hline Consolidated Balance Sheet of the Banking System ${ }^{2}$ & June 2009 & Nov. 2009 & A & Staff visits & NA \\
\hline Interest Rates ${ }^{2,3}$ & June 2009 & Nov. 2009 & A & Staff visits & NA \\
\hline Consumer Price Index & Sept. 2009 & Nov. 2009 & Q & Q & Q \\
\hline $\begin{array}{l}\text { Revenue, Expenditure, Balance/Composition of } \\
\text { Financing }{ }^{4} \text { General Government }{ }^{5} \text { and Central } \\
\text { Government }\end{array}$ & FY2008 & Nov. 2009 & A & A & A \\
\hline $\begin{array}{l}\text { Stocks of Central Government and Central Government- } \\
\text { Guaranteed Debt }\end{array}$ & FY2008 & Nov. 2009 & $A$ & $A$ & A \\
\hline External Current Account Balance & FY2008 & Nov. 2009 & A & Staff visits & NA \\
\hline Exports and Imports of Goods and Services & FY2008 & Nov. 2009 & A & Staff visits & NA \\
\hline GDP/GNP & FY2008 & Nov. 2009 & $A$ & Staff visits & NA \\
\hline Gross External Debt & FY2008 & Nov. 2009 & $A$ & A & A \\
\hline International Investment Position ${ }^{7}$ & NA & NA & I & 1 & I \\
\hline
\end{tabular}

1 Any reserve assets that are pledged of otherwise encumbered should be specified separately. Also, data should comprise short-term liabilities linked to a foreign currency but settled by other means, as well as the notional values of financial derivatives to pay and to receive foreign currency, including those linked to a foreign currency but settled by other means.

2 Annual data is prepared for inclusion in the Annual Compact Report, The Banking Commissioner provided three-quarter FY2009 data for the mission.

3 Both market-based and officially determined, including discount rates, money market rates, rates on treasury bills, notes and bonds.

4 Foreign, domestic bank, and domestic nonbank financing.

5 The general government consists of the central government (budgetary funds, extra budgetary funds, and social security funds) and state and local governments.

6 Including currency and maturity composition.

7 Includes external gross financial asset and liability positions vis-à-vis nonresidents.

8 Daily (D), Weekly (W), Monthly (M), Quarterly (Q), Annually (A); Irregular (I); Not Available (NA) 


\section{INTERNATIONAL MONETARY FUND}

Public Information Notice (PIN) No. 10/30

FOR IMMEDIATE RELEASE

February 23, 2010
International Monetary Fund

$70019^{\text {th }}$ Street, NW

Washington, D. C. 20431 USA

\section{IMF Executive Board Concludes 2009 Article IV Consultation with the Republic of the Marshall Islands}

On February 1, 2010, the Executive Board of the International Monetary Fund (IMF) concluded the Article IV consultation with Republic of the Marshall Islands (RMI). ${ }^{1}$

\section{Background}

Large and stable external grants have buttressed economic growth in the RMI, but this support is time limited. The 2004 Compact of Free Association with the United States (Compact) provides a 20-year stream of funding aimed at strengthening education, health services, and infrastructure projects. These grants have been a boon to social and economic growth, but have come at the expense of fostering economic dependence on foreign income. The economy is dominated by a large public sector and private businesses contribute little to growth. The banking sector is small.

The global economic turmoil hit the economy hard. The boom in commodity and food prices took a sharp toll on the economy and led in 2008 to the first recession in 10 years. The economy stabilized in 2009 (0 percent growth) helped by sharply falling domestic food and energy prices, new fishing sector activities, and reported increases of remittances. Inflation declined to 0.5 percent in 2009 after reaching 14.7 percent in 2008.

The fiscal balance recorded a small deficit of 0.2 percent of GDP in 2009, roughly

\footnotetext{
${ }^{1}$ Under Article IV of the IMF's Articles of Agreement, the IMF holds bilateral discussions with members, usually every year. A staff team visits the country, collects economic and financial information, and discusses with officials the country's economic developments and policies. On return to headquarters, the staff prepares a report, which forms the basis for discussion by the Executive Board. At the conclusion of the discussion, the Managing Director, as Chairman of the Board, summarizes the views of Executive Directors, and this summary is transmitted to the country's authorities. An explanation of any qualifiers used in summings up can be found here: http://www.imf.org/external/np/sec/misc/qualifiers.htm
} 
unchanged from 2008. Lack of access to capital markets and limited financial assets provided little room to adjust to the large terms of trade shock. Additional grants from donors and higher non-tax income from ship registration fees offset lower tax revenue and higher spending.

Gross public debt is high, but counterbalanced by assets in the Compact Trust and social security funds. Government and government guaranteed debt reached 62 percent of GDP in 2008 and are mostly on concessional terms (40 percent of GDP owed to the Asian Development Bank). The collapse in global equity markets in 2008 led to significant losses for the Compact Trust Fund (CTF), but the value of assets recovered (63 percent of GDP in 2009). Similarly, the Social Security Fund rebounded to 46 percent of GDP in 2009, but remained below its 2007 peak.

The economy is on a path to recovery. A gradual expansion with growth reaching 0.5 percent in 2010 is supported by further growth in the fish processing industry and additional foreign grant assistance. However, the cresting of foreign grants will slow the underlying growth momentum to a medium-term growth rate of 1.5 percent. Risks to the economic outlook are tilted to the downside. The economy's high import dependence means that fluctuations in commodity pose a substantial risk to real incomes. Rising prices could stoke inflation and stifle domestic demand. In the current, weak global economic environment, donor assistance may also be more difficult to secure, posing another downside risk to growth.

The global crisis has raised the challenge of achieving long-term budgetary self-reliance and sustained growth. Under current projections, weakened growth prospects and lower than anticipated asset values in the government's trust fund imply a large projected revenue shortfall in 2024, when the U.S. Compact is set to expire. Closing the revenue gap would require a substantial fiscal adjustment over the medium term.

\section{Executive Board Assessment}

Executive Directors were encouraged by growing signs of economic recovery following the 2008 recession. New activities in the fishing sector and increases in remittances have stabilized the economy, and inflation has dropped from its very high levels recorded in 2008. Directors noted that the strength of the recovery depends largely on the availability of foreign grants and job creation in the private sector. In view of rising debt-service payments and the expected decline in foreign grants, fiscal consolidation and public sector reforms are of highest priority. Sustaining economic growth over the long term will require broad-based structural reforms to promote private sector development and increase the resilience of the economy to external shocks.

Directors underscored the need to begin the fiscal consolidation process in 2010 by targeting a sufficiently large fiscal surplus, with a view to increasing savings in the CTF. Given a significant revenue gap projected for 2024 after funding through the Compact of Free Association with the United States expires, it will be important to sustain a large fiscal adjustment over time. In this regard, Directors welcomed the authorities' intention to develop a medium-term comprehensive adjustment plan, combining expenditure and revenue reform proposals to generate lasting fiscal surpluses. They suggested that 
consolidation begin with cuts to the public wage bill, elimination of untargeted electricity and housing allowances, and adjustment of electricity tariffs to cost-recovery levels. Directors encouraged the authorities to launch a comprehensive tax reform, focusing on replacing the general revenue tax with a net profit tax, introducing a consumption tax, reforming the income tax, and unifying tax administrations.

Directors stressed the importance of attaining a growth path consistent with domestic and external stability through structural reforms aimed at fostering private sector growth and competitiveness. A key priority is the reform of state-owned enterprises to improve electricity and telecommunication services, while scaling back the operations of those involved in commercial activities. Wage and price flexibility would help maintain external stability in the context of dollarization.

Directors welcomed efforts to strengthen banking supervision, particularly plans to modernize the Banking Act. Noting the high level of household indebtedness, they considered it prudent to enhance the monitoring of lending operations by banks. Directors also saw the need to tighten the oversight of the public development bank, by bringing it under the supervision of the Banking Commission. Further efforts are necessary to facilitate the use of land as collateral through land registration, and to improve data collection and reporting.

Directors encouraged the authorities to continue to strengthen the statistical base, especially the coverage and timeliness of fiscal and balance of payments data, in order to improve policy analysis and decision-making.

Public Information Notices (PINs) form part of the IMF's efforts to promote transparency of the IMF's views and analysis of economic developments and policies. With the consent of the country (or countries) concerned, PINs are issued after Executive Board discussions of Article IV consultations with member countries, of its surveillance of developments at the regional level, of post-program monitoring, and of ex post assessments of member countries with longer-term program engagements. PINs are also issued after Executive Board discussions of general policy matters, unless otherwise decided by the Executive Board in a particular case. 
Marshall Islands: Selected Economic Indicators FY2004-09 1/

\begin{tabular}{|c|c|c|c|c|c|c|}
\hline & 2004 & 2005 & 2006 & 2007 & $\begin{array}{r}\text { Est. } \\
2008\end{array}$ & $\begin{array}{l}\text { Proj. } \\
2009\end{array}$ \\
\hline \multicolumn{7}{|l|}{ Real sector } \\
\hline Real GDP (percent change) & 4.0 & 0.7 & 2.4 & 3.3 & -2.0 & 0.0 \\
\hline Consumer prices (percent change) & 2.0 & 3.5 & 5.3 & 2.6 & 14.7 & 0.5 \\
\hline \multicolumn{7}{|l|}{ Central government finances (in percent of GDP) } \\
\hline Revenue and grants & 57.1 & 70.9 & 74.8 & 71.7 & 70.4 & 67.9 \\
\hline Total domestic revenue & 25.1 & 25.6 & 25.1 & 25.5 & 25.7 & 23.9 \\
\hline Grants & 32.0 & 45.3 & 49.6 & 46.1 & 44.7 & 43.9 \\
\hline Expenditure & 58.4 & 74.2 & 73.4 & 71.4 & 70.6 & 68.1 \\
\hline Current & 50.1 & 55.9 & 54.2 & 54.4 & 58.5 & 54.3 \\
\hline Capital & 8.4 & 18.4 & 19.3 & 17.0 & 12.2 & 13.8 \\
\hline Overall balance & -1.3 & -3.4 & 1.3 & 0.2 & -0.2 & -0.2 \\
\hline $\begin{array}{l}\text { Compact Trust Fund (in millions of US\$; end of } \\
\text { period) }\end{array}$ & 32.0 & 48.9 & 63.1 & 85.5 & 75.7 & 97.3 \\
\hline \multicolumn{7}{|l|}{$\begin{array}{l}\text { Commercial banks (in millions of US\$; } \\
\text { end-December) } 2 /\end{array}$} \\
\hline Foreign assets & 51.0 & 53.6 & 57.6 & 60.7 & 57.1 & 61.7 \\
\hline Private sector claims & 43.4 & 43.6 & 43.2 & 49.9 & 58.2 & 61.2 \\
\hline Total deposits & 74.9 & 74.3 & 75.5 & 85.5 & 89.0 & 91.8 \\
\hline One-year time deposit rate (in percent) & 2.1 & 3.5 & 4.0 & 4.1 & 3.6 & 6.0 \\
\hline Average consumer loan rate (in percent) & 17.4 & 18.5 & 18.5 & 18.5 & 18.5 & 13.9 \\
\hline \multicolumn{7}{|l|}{ Balance of payments (in millions of US\$) } \\
\hline Trade balance & -59.9 & -68.5 & -74.6 & -73.8 & -74.9 & -71.0 \\
\hline Net services & -22.1 & -27.0 & -27.6 & -30.9 & -32.1 & -31.7 \\
\hline Net income & 32.2 & 35.0 & 36.4 & 34.4 & 31.8 & 30.5 \\
\hline Unrequited transfers (private and official) & 45.9 & 52.1 & 55.5 & 63.2 & 63.0 & 60.1 \\
\hline $\begin{array}{l}\text { Current account including official current } \\
\text { transfers } 3 /\end{array}$ & -3.8 & -8.4 & -10.3 & -7.1 & -12.2 & -12.1 \\
\hline (In percent of GDP) & -2.8 & -6.1 & -7.1 & -4.7 & -8.0 & -7.9 \\
\hline \multirow{2}{*}{$\begin{array}{l}\text { Current account excluding budget grants } 3 / \\
\text { (In percent of GDP) }\end{array}$} & -43.8 & -54.3 & -59.8 & -60.7 & -69.4 & -66.4 \\
\hline & -32.9 & -39.2 & -41.3 & -40.2 & -45.7 & -43.4 \\
\hline \multirow{2}{*}{$\begin{array}{l}\text { External debt (in millions of US\$; end of period) } \\
4 / \\
\text { (In percent of GDP) }\end{array}$} & 94.7 & 92.1 & 99.7 & 98.5 & 94.3 & 89.9 \\
\hline & 71.1 & 66.4 & 69.0 & 65.2 & 62.0 & 58.9 \\
\hline \multirow{2}{*}{$\begin{array}{l}\text { External debt service (in millions of US\$) } \\
\text { (In percent of exports of goods and services) }\end{array}$} & 3.8 & 4.5 & 6.9 & 16.2 & 7.8 & 12.2 \\
\hline & 15.5 & 16.0 & 36.4 & 72.6 & 31.5 & 59.3 \\
\hline \multicolumn{7}{|l|}{ Exchange rate } \\
\hline Real Effective Exchange Rate $(1995=100)$ & 94.6 & 94.5 & 97.0 & 96.5 & 102.8 & 104.6 \\
\hline \multicolumn{7}{|l|}{ Memorandum Item: } \\
\hline Nominal GDP (in millions of US\$) & 133.3 & 138.6 & 144.6 & 151.0 & 152.0 & 152.8 \\
\hline \multicolumn{7}{|c|}{$\begin{array}{l}\text { Sources: Data provided by the Marshallese authorities; and IMF staff estimates. } \\
\text { 1/ Fiscal year ending September } 30 \text { unless otherwise stated. } \\
\text { 2/ } 2009 \text { data are the average of three quarters. }\end{array}$} \\
\hline
\end{tabular}




\title{
Statement by Hi-Su Lee, Executive Director and Ji-Sung Moon, Advisor to the Executive Director
}

\author{
February 1, 2010
}

\section{Introduction}

1. My RMI authorities wish to express their utmost appreciation to the Fund and its staff for the well-structured report which successfully highlights the country's current economic status and the challenges it faces. The effectiveness of the analysis was enhanced by the joint mission with representatives of the World Bank and the ADB.

2. The RMI's socio-economic environment, such as geographical detachment from major markets, narrow production and export base, and vulnerability to external shocks, has made it difficult to achieve a self-sustaining economy, resulting in heavy dependence on external supports. The authorities are deeply grateful for the continued support from the international community, in particular from the U.S., who has been providing financial support through the Compact of Free Association. The Compact, which was established in 1987 and was renewed and amended in 2003, will last until 2023 and it provides up to 50 to 60 percent of the RMI's Annual Budget of $\$ 120$ million.

3. A no-confidence vote was passed on October 20, 2009 resulting in the election of the former Speaker of the Parliament, Mr. Jurelang Zedkaia, as the new President. In the new government, all but one cabinet post kept their positions, which enabled the RMI to keep policy consistency in achieving long-term economic and fiscal sustainability.

\section{Recent Economic Developments}

4. Despite continuous support from the U.S. Compact, the RMI could not be insulated from the global price hike. Real GDP contracted by 2 percent in 2008, the first recession in 10 years, mainly due to the sharp increase of commodity prices. In 2009, the global crisis had negative impacts on the RMI through both significant declines in the value of CFT assets and the difficulty of getting additional donor assistance.

5. Notwithstanding the stabilization of the economy in 2009, however, my authorities agree that risks to the outlook are tilted to the downside. The significant decline in external grants under the amended Compact, including steady increase in debt service payments and energy and food price hikes, are the main risks to this economy. Accordingly, needless to say, the new Government's prime objective is to maintain a stable macroeconomic environment, with a focus on maintaining a prudent fiscal policy and reforming structural weaknesses.

\section{Main Challenges: Achieving Fiscal Sustainability}

6. Fiscal adjustment to a 5 percent of GDP is a big challenge to the RMI. However, my authorities acknowledged the urgency of fiscal consolidation, noting that delaying the adjustment would just make achieving sustainable growth more difficult. In this vein, the 
authorities fully welcome the staff's suggestions for long-term fiscal sustainability and will take these into consideration in the policy framework in the not-too-distant future.

7. It is commendable that the fiscal balance has remained nearly balanced thus far. To create a fiscal surplus in 2010, my authorities have reflected some of the RMI Budget Coordinating Committee's recommendations in the FY10 budget, which led the government to establish two reform commissions to review the current fiscal structure from two angles, the expenditure side and the revenue side. The Comprehensive Adjustment Program group (CAP) was established to review the government budget from the expenditure side and recommend ways and means to reduce expenditures; and the Tax and Revenue Reform and Modernization Commission (TRRM) was established to review the tax regime and recommend reform measures needed to streamline administrative processes and enhance collection of revenues. Both think-tanks consist of prominent members from the private sector, academics, and the government. We take comfort in the fact that the draft ideas on the table of CAP and TRRM are broadly in line with the Fund's recommendations.

8. Reforming the public sector is one of the top priorities. A comprehensive civil service personnel audit supported by the ADB to find any overlapping is now being undertaken by the Public Service Commission over the three ministries and will be expanded to cover all ministries at a later time. However, actual implementation needs a well-planned strategy to minimize side effects in a country where (i) the government is the single largest employer, (ii) the private sector is not able to absorb any employees from the government, (iii) the current unemployment rate is as high as about $30 \%$, and (iv) the social safety net is not sufficient enough to cover the unemployed.

9. Budgetary support for SOEs is one of the universal obstacles against fiscal soundness. However, consideration should be given to the fact that the RMI consists of small and remote atolls, where meeting economy of scale in infrastructure is really challenging. Public goods and services provided by SOEs have limited competitions by nature. One progress worthy of notice is the recent non-renewal of the contract with Pacific International Inc., which managed the RMI Tobolar Copra Processing Plant for more than 20 years. The new Board recently appointed by the Cabinet decided not to renew the contract to modernize management and operations, with the intention to improve long-term financial viability of the plant, and to reduce its dependence on government subsidy. Staff's recommendation of delineation between commercial and non-commercial services is worthy of further consideration.

\section{Financial Sector Issues}

10. The banking system remains profitable and well capitalized. However, the Banking Commission is well aware of the possible risks from high-interest household loans. My authorities agreed to the need for vigilance in monitoring bank lending and strengthening financial sector supervision, including oversight of the Development Bank. Greater efforts to improve data collection, including loans and remittances, and to issue regular reports for better financial supervision will be continuously made. Moreover, all banks continue to comply with the Banking Act, which requires banks to make sure that 
issues of money laundering and other illegal activities are closely monitored and prevented.

\section{Structuring Issues: Boosting Private Sector Growth}

11. Another priority of the new government is to address structural reforms to cultivate a self-sustaining business sector independent from the Compact and to prepare the country when fundings from the Compact cease in 2023. Tangible steps to decrease administrative delays and to streamline the process of business registration and licensing will be taken. As for the land issue, the authorities have emphasized their strong desire to tackle further the land ownership issue in a consistent manner, while accepting that this will entail considerable time and effort in the future, simply because of the complex nature of the Marshallese land tenure system.

12. Fish processing industry would be one of the main growth engines for the RMI in the future. Once Parties to the Nauru Agreement (PNA), a regional collaboration of eight island nations on the regional fish stock, becomes effective, the RMI would have a better chance of capturing a higher share of fishing profits. The establishment of the PNA Regional Office located in Majuro is in progress and is expected to be officially open for business soon. Continued efforts are also being made to attract more tourists, which should contribute positively to the global economic recovery.

\section{Conclusion}

13. Finally, my RMI authorities wish to express their special appreciation and warm greetings to the Fund staff for their timely and appropriate policy advices. My authorities fully accept the Fund's wake-up call for the need for structural reforms in order to achieve a long-term sustainable growth, and are committed to maintaining a close policy dialogue with the Fund as usual. 